\title{
The Impact of Differential Payroll Tax Subsidies on Minimum Wage Employment
}

Francis Kramarz

Thomas Philippon

Research Memorandum 0006

OCFEB

Research Centre for Economic Policy

P.O. Box 1738

3000 DR Rotterdam

The Netherlands

e-mail: ae-OCFEB-secr@few.eur.nl

telephone +31 10408 2430/2446

telefax +31 104089173 


\title{
The Impact of Differential Payroll Tax Subsidies on Minimum Wage Employment
}

\author{
Francis Kramarz, CREST- INSEE, CNRS, and CEPR
}

Thomas Philippon, MIT

The authors would like to thank two anonymous referees as well as David Card, Bart Cockx, Bruno Crépon, Jennifer Hunt, Steve Machin, Thomas Piketty and Paolo Sestito for very helpful comments and suggestions. We would also like to thank participants at the CEPR-Brussels Conference on minimum wage, the CNRS winter workshop in Aussois, and at the CREST, Hebrew University in Jerusalem, IZA, LSE, University of Bonn, UCL, and University of Toulouse-IDEI seminars for their remarks on previous versions of this paper.

Corresponding author: Francis Kramarz, Crest-Insee, 15 bd Gabriel Péri, 92245 Malakoff, France, e-mail : kramarz@ensae.fr.

The data were taken from the "Enquête Emploi" research files constructed by the Institut National de la Statistique et des Etudes Economiques (INSEE, the French national statistical agency). For further information contact: INSEE, Département de la diffusion, 18 bd Adolphe Pinard, 75675 Paris Cedex 14, France. 


\section{Table of contents}

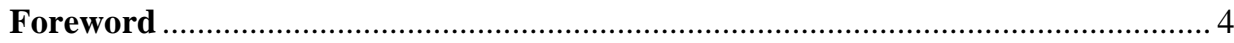

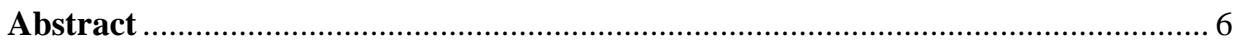

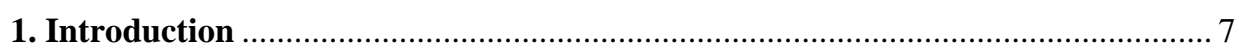

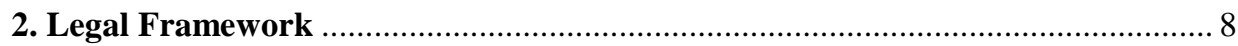

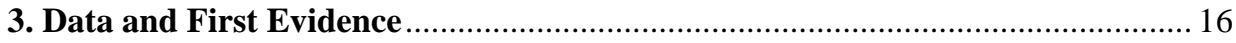

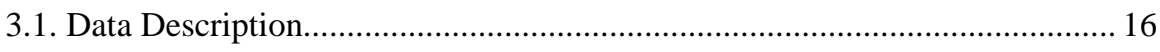

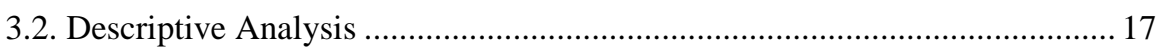

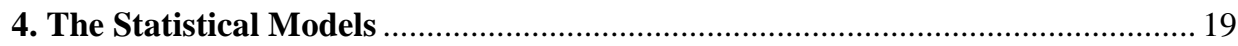

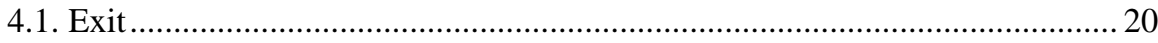

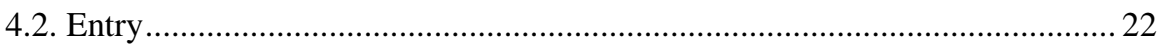

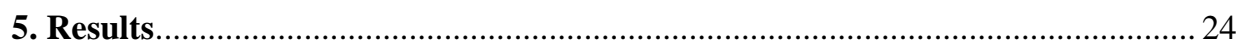

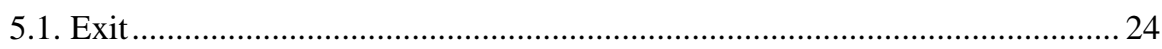

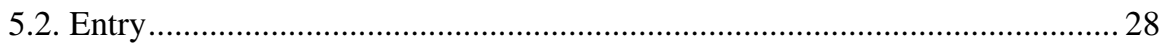

5.3. Are "Marginal" Workers a Good Control Group ? .................................. 31

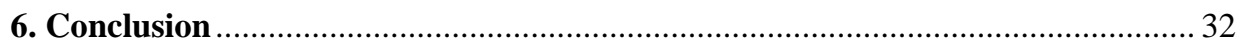

References

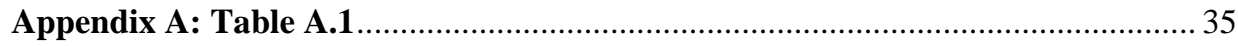

Appendix B: Transitions Within the Wage Distribution .................................. 36 


\section{Foreword}

One of the most challenging and at the same time still controversial topics in labor economics is the effect of the minimum wage on labor market outcomes. This research memorandum was presented at a workshop organized by OCFEB and the Tinbergen Institute in April 2000. The focus was on recent developments in the analysis of the minimum wage. A mix of theory and empirical papers were presented at this workshop. The theory papers show that frictionless Walrasian models are not able to explain the stylized facts. Instead, we need modern economic theories which deal with imperfect information and other market imperfections to derive novel insights into these effects. The empirical papers show how a careful empirical analysis can shed new lights on the magnitudes of the effects. Below we give a short overview of all the papers that were presented at the workshop.

The Research Memorandum 0004 by Sonia Pereira (University College London), "The impact of minimum wages on youth employment in Portugal", is about a natural experiment in Portugal. From January 1, 1987, the legal minimum wage for workers aged 18 and 19 in Portugal was raised to the full adult rate, generating a $49.3 \%$ increase between 1986 and 1987 in the legal minimum wage for this age group. This shock is used to evaluate the impact of the minimum wage change on teenagers' employment. Her conclusion is that the rise in the minimum wage significantly reduced employment.

The Research Memorandum 0005 of Chris Flinn (New York University), "Interpreting minimum wage effects on wage distributions: a cautionary tale", argues that welfare effects of minimum wage effects can only be drawn by using empirical evidence on employment changes, the wage distribution and a formal model in which welfare can be defined in a meaningful and rigorous way. Flinn shows that negative employment effects by itself do not tell us much about the aggregate welfare effects of the minimum wage.

The Research Memorandum 0006 of Francis Kramarz and Thomas Philippon (University of Paris I, CREST, and MIT respectively), "The impact of differential payroll tax subsidies on minimum wage employment", uses changes in compensation costs and minimum wages, to get observations of up- and down- variation in real minimum wages. They get up-and down-movements in minimum wages in the US, with differentiation by state, and in France an equivalent-minimum is defined, which normalizes on the compensation cost in a base year and looks at variations in the underlying minimum and payroll taxes to get up- and down-variation in the equivalent minimum in France. They find no significant effects in the United States but strong and significant effects in France.

In the Research Memorandum 0007 by Pieter Gautier and Coen Teulings (Erasmus University Rotterdam, Tinbergen Institute, OCFEB), "A large piece of a small pie: minimum wages and unemployment benefits in an assignment model with search 
frictions", an assignment model with search frictions is offered that is consistent with the following stylized facts: a spike at the minimum wage, compression of wage differentials at a large interval above the minimum wage and small employment losses. The introduction of a minimum wage in their model makes some matches at the lower segments no longer profitable. In addition it leads to a redistribution of rents from firms to low skilled workers. A minimum wage fulfills a potential useful role in this model in the sense that it prevents low skilled workers from accepting jobs for which they are ill suited.

Finally, Research Memorandum 0002 by Gerard van den Berg (Free University Amsterdam, Tinbergen Institute, CEPR, OCFEB), "Multiple equilibria and minimum wages in labor markets with informational frictions and heterogeneous production technologies", discusses an equilibrium search model in which imposition of a minimum wage affects wages even though, after imposition, the lowest wage in the market is strictly larger than the minimum wage and there is no spike, so that it seems that the minimum wage is irrelevant. The minimum wage effects are a consequence of the fact that the model has multiple equilibria. This, in turn, is because the reservation wage of the unemployed and the lowest production technology in use affect each other. He shows that multiplicity is an empirically relevant phenomenon, using data from Denmark and the United States. A minimum wage policy can be fruitfully applied to single out the desirable equilibrium.

Gerard J. van den Berg

Pieter A. Gautier 
The Impact of Differential Payroll Tax Subsidies on Minimum Wage Employment

\begin{abstract}
In this paper, we study the impact of changes of total labor costs on employment of lowwage workers in France in a period, 1990 to 1998, that saw sudden and large changes in these costs. We use longitudinal data from the French Labor Force survey («enquête emploi ») in order to understand the consequences of real decreases and real increases of the labor cost. We examine the transition probabilities from employment to nonemployment and from non-employment to employment. In particular, we compare the transition probabilities of the workers that were directly affected by the changes ("between" workers) with the transition probabilities of workers closest in the wage distribution to those directly affected ("marginal" workers). In all years with an increasing minimum wage cost, the "between" group (or the treated using the vocabulary of controlled experiments) comprises all workers whose costs in year $t$ lie between the old (year $t$ ) and the new (year $t+1)$ minimum. In all years with a decreasing minimum, the "between" group comprises all workers whose costs in year $t+l$ lie between the present minimum wage cost (year $t+l$ ) and the old (year $t$ ) minimum wage cost. The results can be summarized as follows. Comparing years of increasing and decreasing minimum wage cost, difference-indifference estimates imply that an increase of $1 \%$ of the cost implies roughly an increase of $1.5 \%$ in the probability of transiting from employment to non-employment for the treated workers, the resulting elasticity being -1.5 . Second, results for the transitions from nonemployment to employment are less clear-cut. Tax subsidies have a small and insignificant impact on entry from non-employment as well as on transitions within the wage distribution. Finally, there is no obvious evidence of substitution between the "between" and "marginal" groups of workers, but there is some evidence of substitution between workers within the tax subsidy zone, with wages above those of the "marginal", and workers outside the subsidy zone.
\end{abstract}

Keywords: Minimum Wage, Total Labor Costs, Tax Subsidies

JEL Classifications: J31, J23

Francis Kramarz

CREST-INSEE and CEPR

Département de la Recherche

15, bd Gabriel Péri

92245 Malakoff Cedex.

France

kramarz@ensae.fr
Thomas Philippon

MIT

Department of Economics

50, Memorial Drive

Cambridge, MA, 02142-1347

USA

philippo@mit.edu 


\section{Introduction}

The importance of the impact of minimum wages on labor market outcomes is a matter of considerable debate. Some argue that minimum wage changes have no visible impact on employment (see the discussions surrounding the Card and Krueger', 1994 study; see also Card and Krueger, 1998 and Card and Krueger, 1995 for a recent critical analysis of the literature; see also Dickens, Machin, and Manning, 1998 for an analysis of the UK). Some others however, find that the falling real minimum wage over the eighties had impact both on employment of young as well as adult workers, and on the increase in wage inequality in the U.S. (see Brown, Gilroy, and Kohen, 1982 for the classic survey of the employment effects of minimum wages; Brown, 1999 for a new comprehensive survey; Dolado, Kramarz, Machin, Manning, Margolis, and Teulings, 1996 for a European perspective; Neumark and Washer, 1992 for the US, Abowd, Kramarz, Lemieux, and Margolis, 1999 for young workers or Abowd, Kramarz, and Margolis, 1999 for adult workers both in France and in the US; and DiNardo, Fortin, and Lemieux, 1996, and Lee, 1999 for inequality).

All these studies, indeed almost all existing ones, use wages as a good measure of total labor costs for the low-wage labor market in the U.S. This measure however, is far from being adequate in Continental Europe. Indeed, in France, for a worker paid at the minimum wage, employee-paid contributions increased from $12.22 \%$ of the wage in 1980 to $20.02 \%$ at the beginning of 1993 whereas employer-paid contributions remained roughly stable (from $39.00 \%$ to 39.19\%). But, starting in 1993, the employer-paid contributions started to decrease for minimum-wage workers (from $36.49 \%$ of the wage in 1993 to $21.77 \%$ in 1996), even though the minimum wage increased steadily over the period. Furthermore, the subsidies increased dramatically and, maybe, unexpectedly, between 1995 and 1996.

In this paper, we study the impact of changes of total labor costs on employment of lowwage workers in France in the period 1990-1998, that saw steady increases followed by sudden and large decreases in the minimum wage costs. The tax subsidies were expected to counteract the negative impact of high minimum wage costs in a country with a large unemployment rate, in particular for young and uneducated workers.

We use longitudinal data from the French Labor Force survey («enquête emploi ») in order to understand the consequences of real decreases and real increases of the labor cost. We examine the transition probabilities from employment to non-employment and from non-employment to employment. To estimate the effects of the changes in the costs, we compare these transitions between years as well as within a year. In particular, we compare the transition probabilities of the workers that were directly affected by the changes, the "between" workers, with the transition probabilities of workers closest in the wage distribution to those directly affected, the "marginal" workers. In all years with an increasing minimum wage cost, the "between" group (the treated using the vocabulary of controlled experiments) comprises all workers whose costs in year $t$ lie between the old (year $t$ ) and the new (year $t+l$ ) minimum. In those years, we examine whether these workers lose employment more frequently than workers paid 
marginally above the new minimum wage cost (the control group). In all years with a decreasing minimum, the "between" group comprises all workers whose costs in year $t+l$ lie between the present minimum wage cost (year $t+1$ ) and the old (year $t$ ) minimum cost. In those years, we examine whether such workers come more often from non-employment than those paid marginally above the old minimum wage cost (the "marginal" group). We complement the first (simple difference) estimates with a difference-in-difference analysis in which the gap in employment to non-employment transitions between the treated group and the control group, in years of increasing minimum wage costs, is compared to the same gap in years of decreasing minimum wage costs. Similarly, we compare the gap in non-employment to employment transitions between the "between" group and the "marginal" group in years of decreasing minimum wage costs with the one observed in years of increasing costs.

The results can be summarized as follows. Comparing years of increasing minimum wage cost and decreasing cost, difference-in-difference estimates imply that an increase of $1 \%$ of the cost implies roughly an increase of $1.5 \%$ in the probability of transiting from employment to non-employment for the treated workers, the resulting elasticity being -1.5 . There is strong evidence that the effects of cost increases and decreases are not symmetric. Unfortunately, the results for the transitions from non-employment to employment are less clear-cut. Even though tax subsidies seem to have an impact on entry from non-employment, this effect is not significantly different from zero. Tax subsidies also appear to have an effect on transitions within the wage distribution.

In the next section, we present the legal framework surrounding the changes in the minimum wage and in the payroll taxes and their impact of the costs of workers paid around the minimum wage. In Section 3, we present the data that we use as well as first descriptive evidence. In Section 4, we specify our statistical models; the resulting estimates being presented in Section 5. We briefly conclude in Section 6.

\section{Legal Framework}

The first minimum wage law in France was enacted in 1950, creating a guaranteed hourly wage rate that was partially indexed to the rate of increase in consumer prices. Beginning in 1970, the original minimum wage law was replaced by the current system (called the SMIC, "salaire minimum interprofessionnel de croissance") linking the changes in the minimum wage to both consumer price inflation and growth in the average hourly bluecollar wage rate. In addition to formula-based increases in the SMIC, the government legislated increases many times over the next two decades (the so-called "coup de pouce"). The statutory minimum wage in France regulates the hourly regular cash compensation received by an employee, including the employee's part of any payroll taxes. ${ }^{1}$

1 Other features of the French labor market are described in Card, Kramarz, and Lemieux (1999). But, the minimum wage is an essential component of the French labor market institutions. 
Figure 1 shows for our sample period the changes in the French minimum wage (i.e. including the associated employee-paid payroll taxes) and the changes in the associated total labor costs (i.e. including the employer-paid payroll taxes) in March of every year.

Figure 1: Changes in the Real Minimum Cost and the Real Minimum Wage

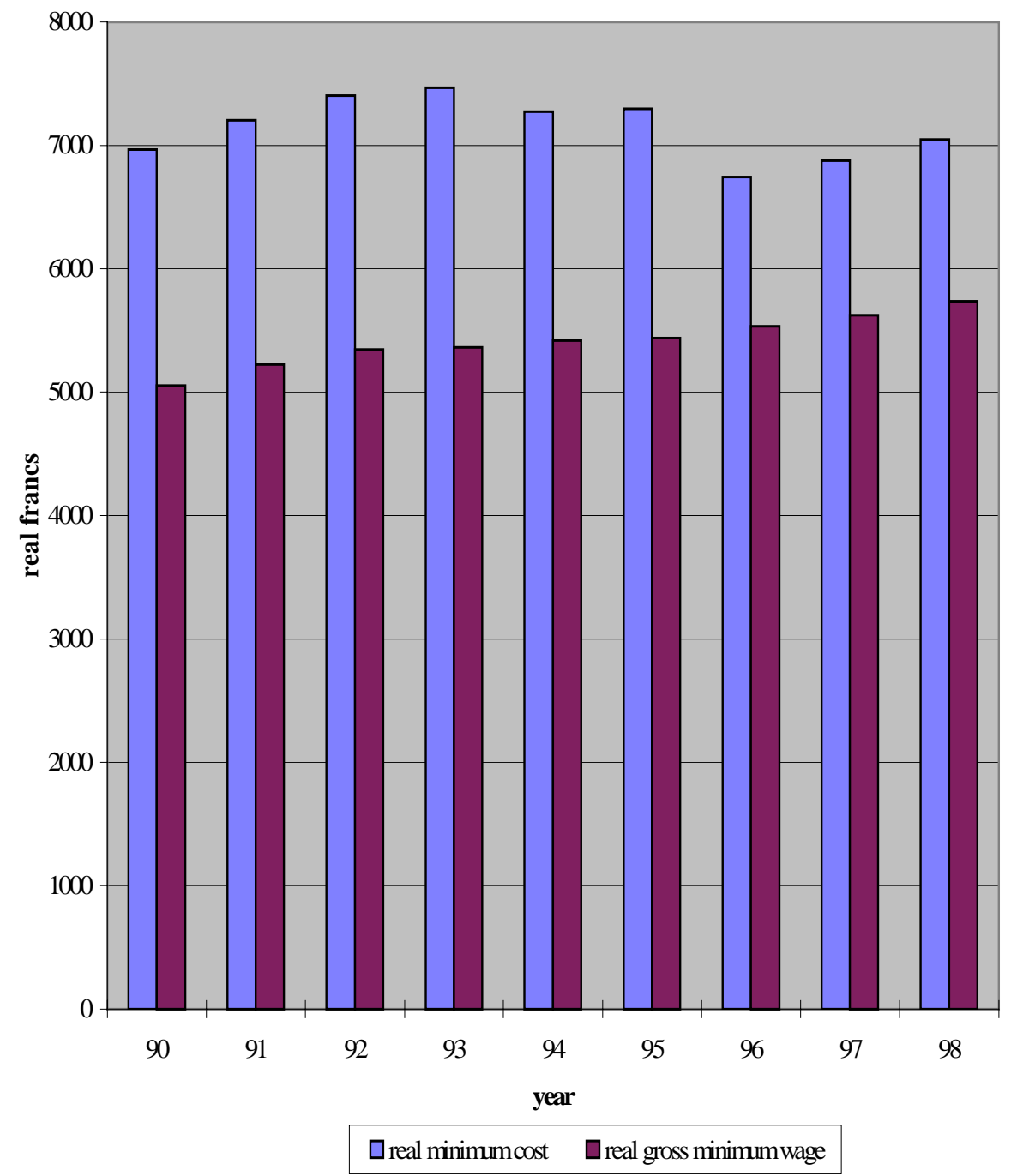

Sources: Dares (various years), Insee (various years)

Because of the extensive use of payroll taxes to finance mandatory employee benefits, the French minimum wage imposed a substantially greater cost upon the employer than 
its statutory value. In addition, the real (statutory) minimum wage increased over the whole period, partly because of increases in the employee-paid payroll taxes, partly because of the voluntary policy of the various French governments. To counteract this increasing burden, tax exemptions were enacted during this period. Figure 2 presents the various policies that were successively implemented over the nineties. The year refers to the situation in March, month of the French labor force survey, the data that we use in the following. In March 1994, the subsidy is made of two flat rates, the first one, ranging from 1 to 1.1 times the minimum wage, is equal to $5.4 \%$, while the second, ranging from 1.1 to 1.2 times the minimum wage, is equal to $2.7 \%$. In 1995 , the ranges became respectively 1-1.2 and 1.2-1.3. In September 1995 (dated 1996 in Figure 2), the subsidy increased dramatically and its shape changed, decreasing from $18 \%$ to $5.4 \%$ for wages going from 1 times the minimum wage to 1.2 times the minimum wage. In October 1996 (dated 1997 in Figure 2), the two subsidies were merged in one linear reduction that spanned from 1 to 1.33 times the minimum wage. In 1998, the subsidy did not change.

Figure 2: The Tax Subsidies, 1994 to 1998

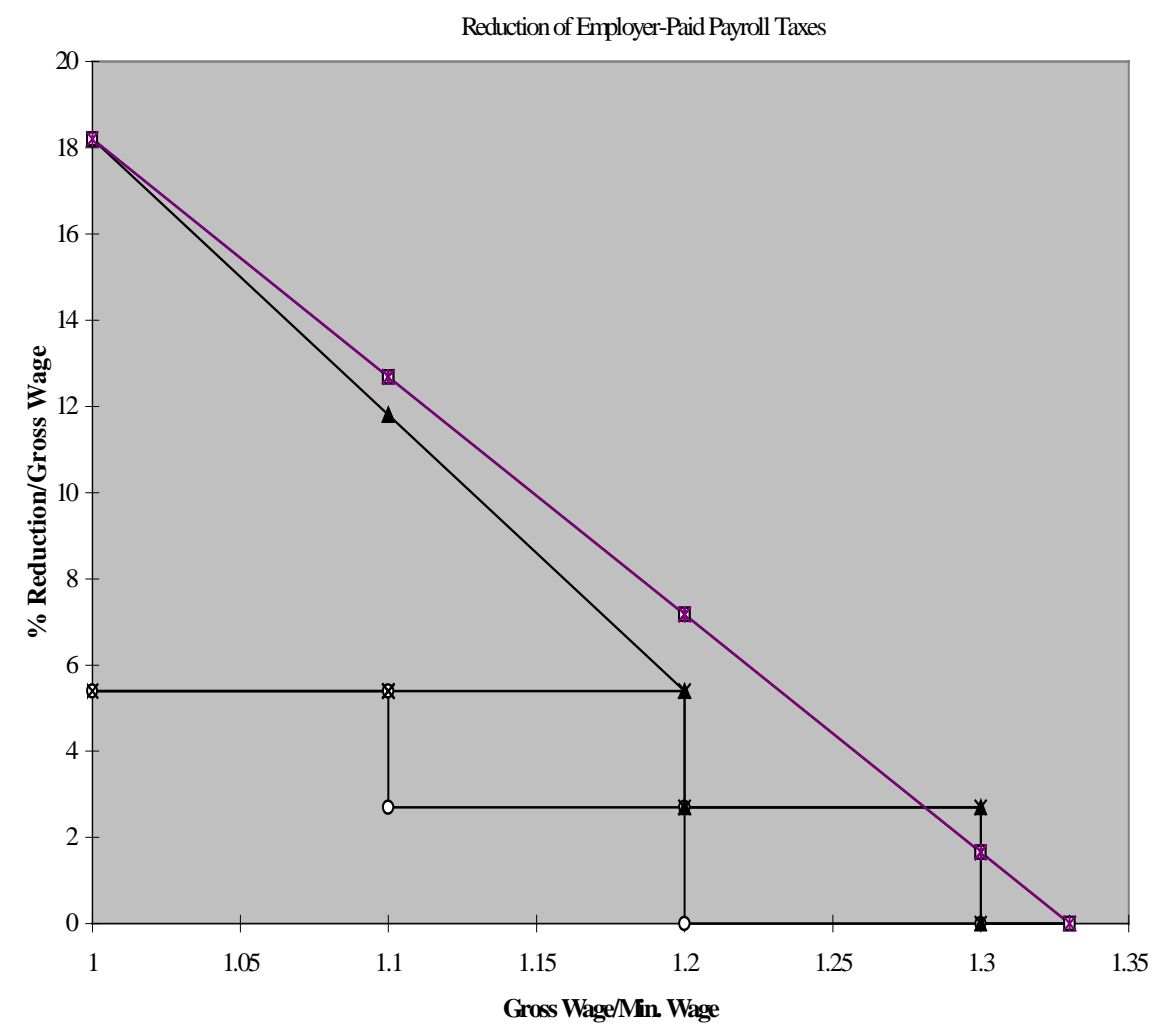


Hence, between 1993 and 1995, the tax reductions were rather small (at most 6\% for a minimum wage worker). But, starting in September 1995, reductions became substantial and the employer-payroll taxes decreased by 18 percentage points at minimum wage. Employer-paid payroll taxes went from roughly $40 \%$ at the beginning of the nineties to $21.77 \%$ in 1996 . The next figures show the impact of the subsidies on the changes of costs for workers with a wage between the minimum wage and twice the minimum wage for the various years of our sample.

\section{Figure 3a: Changes in Costs, 1990-1991}

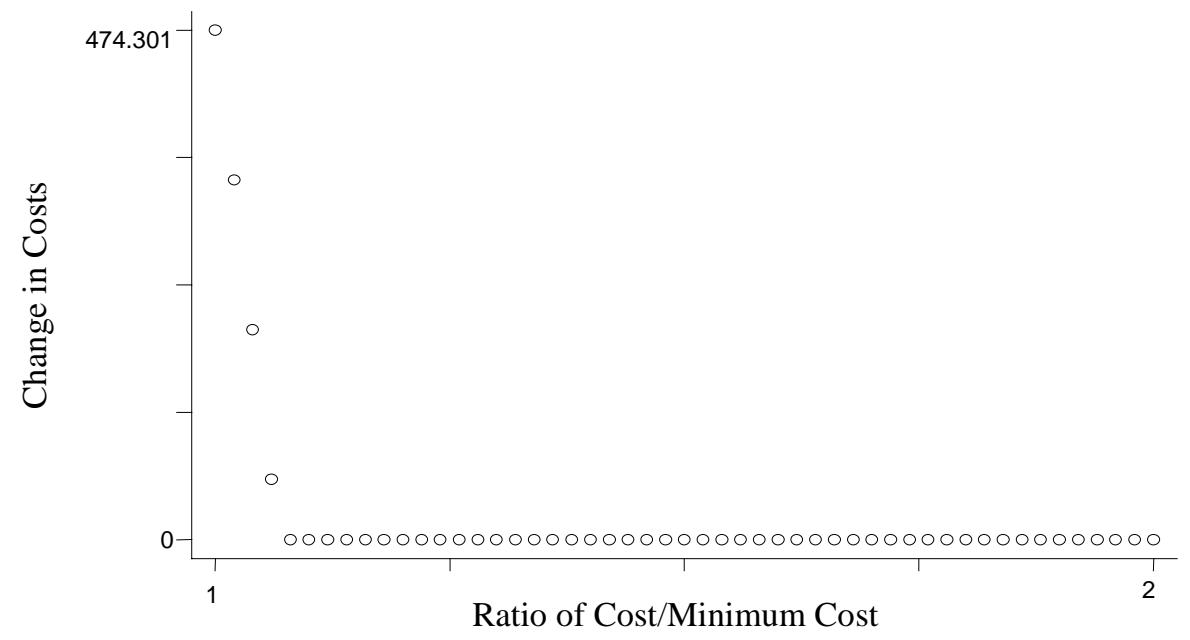

Figure 3b: Changes in Costs, 1991-1992

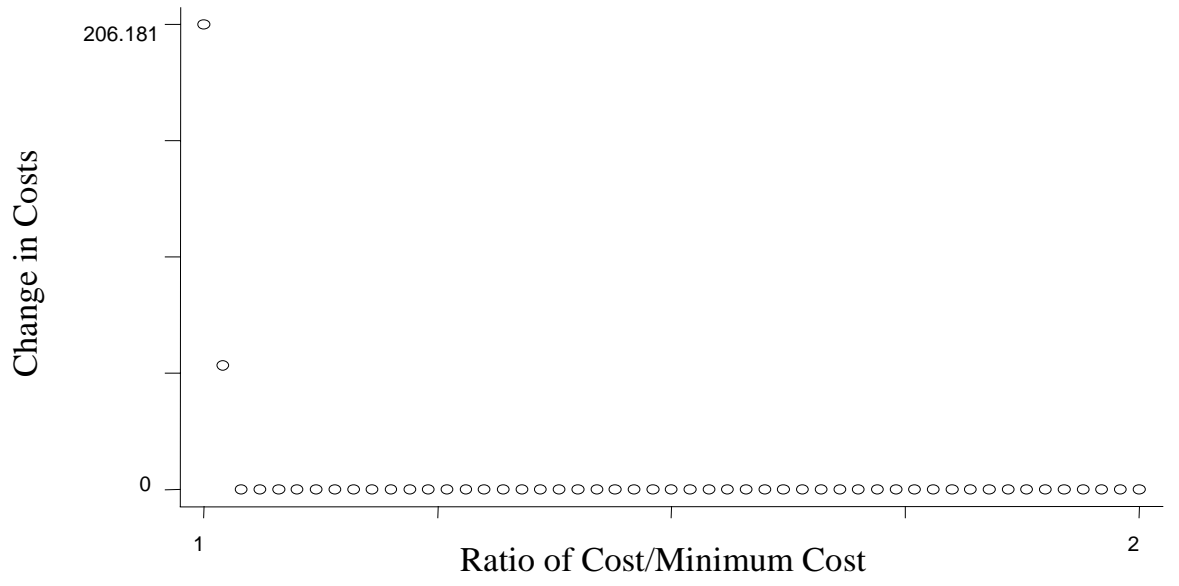


Figure 3c: Changes in Costs, 1992-1993

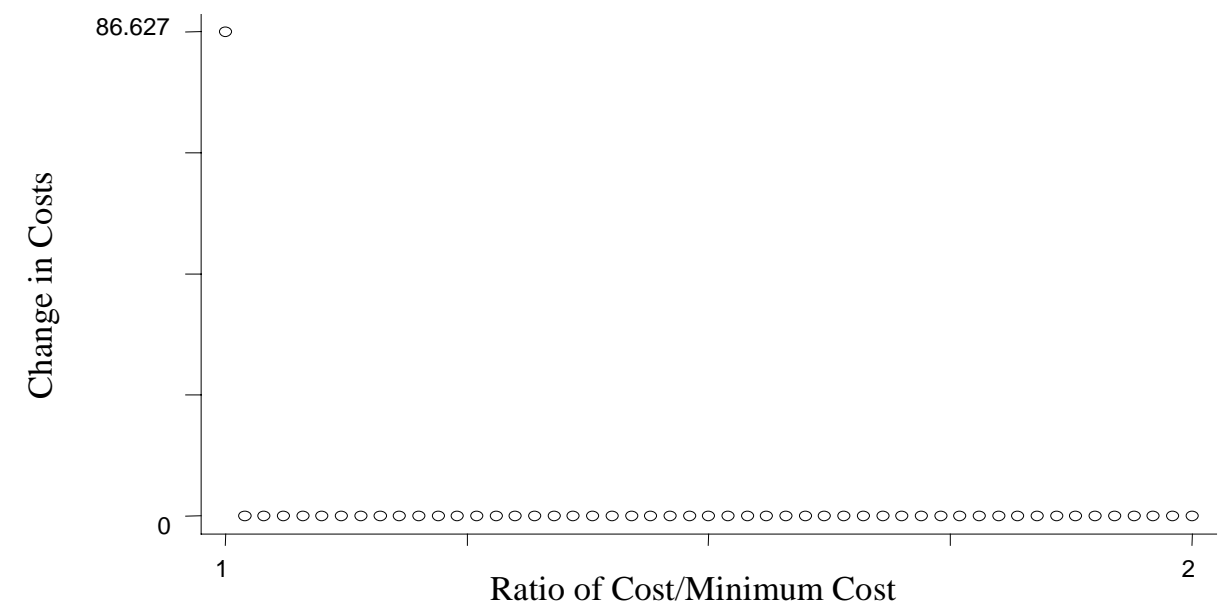

Figure 3d: Changes in Costs, 1993-1994

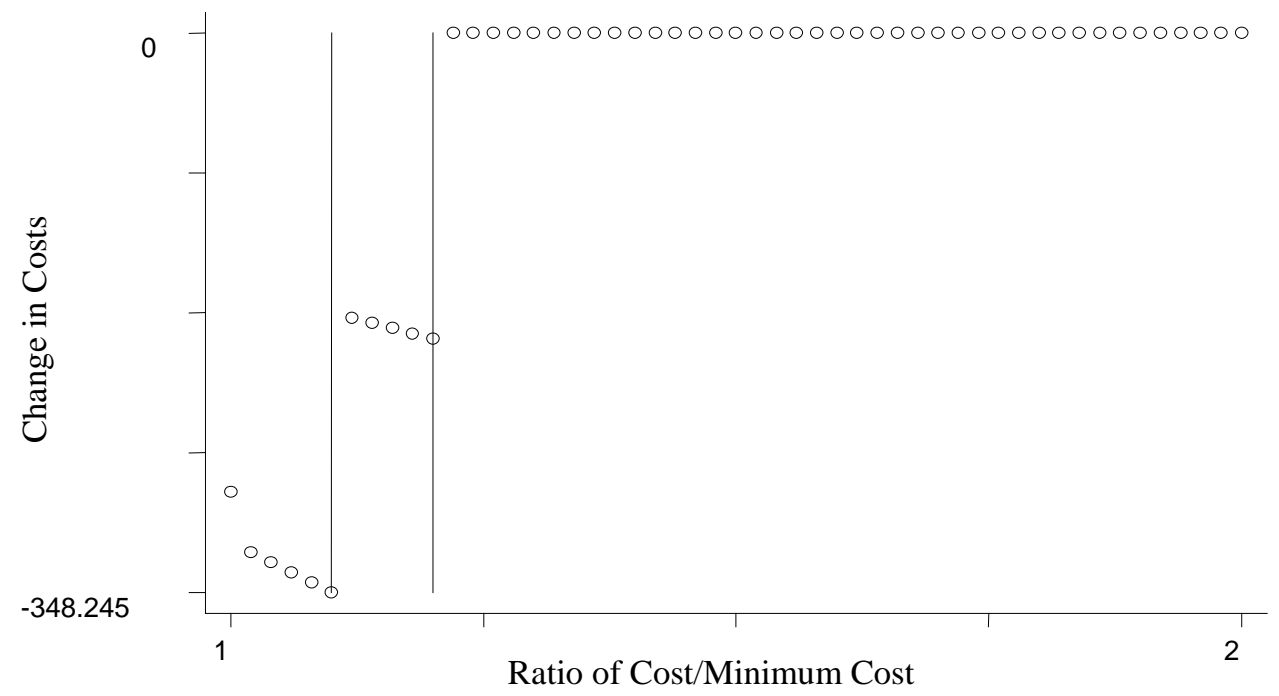

12 
Figure 3e: Changes in Costs, 1994-1995

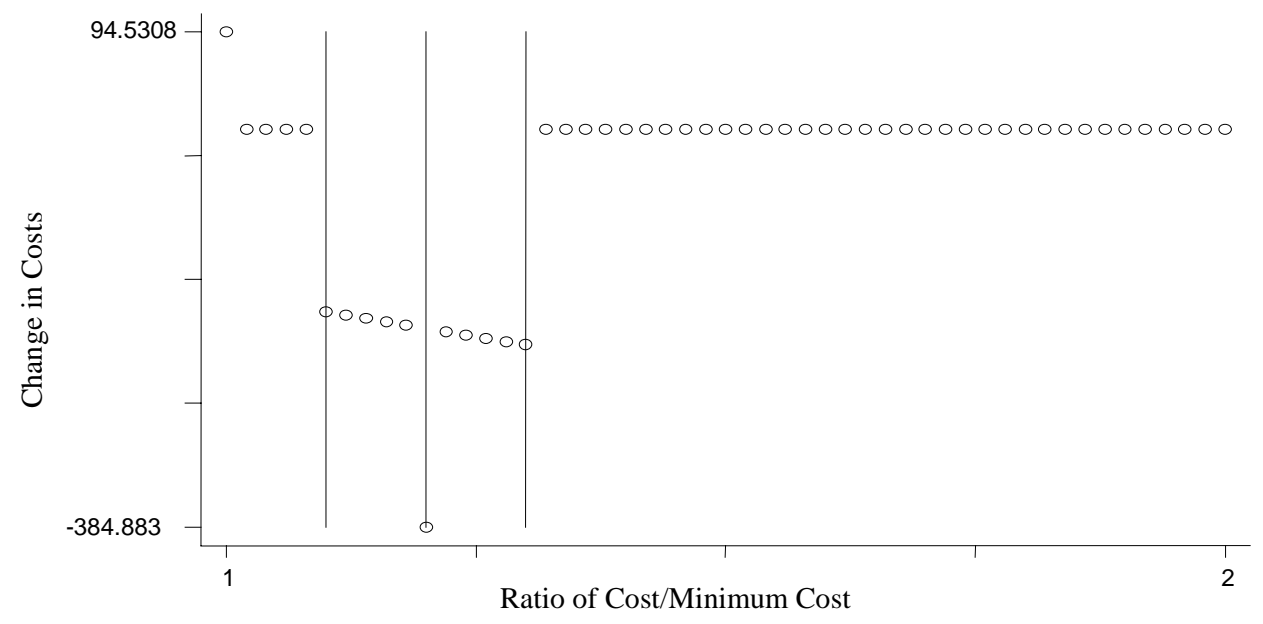

Figure 3f: Changes in Costs, 1995-1996

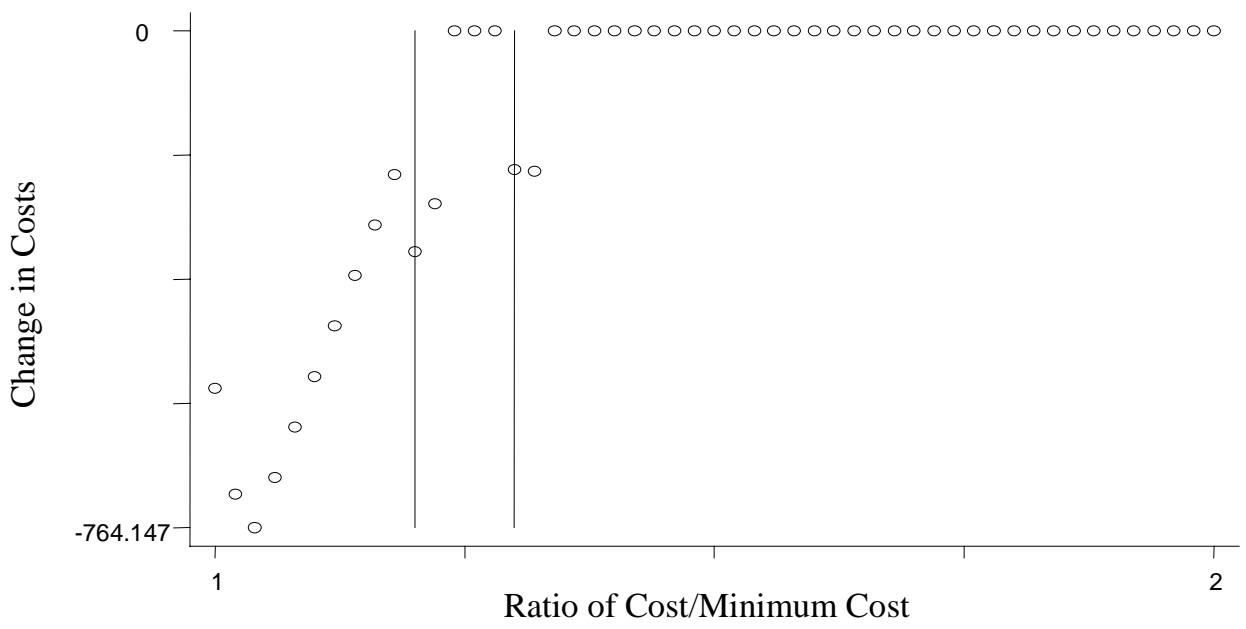


Figure 3g: Changes in Costs, 1996-1997

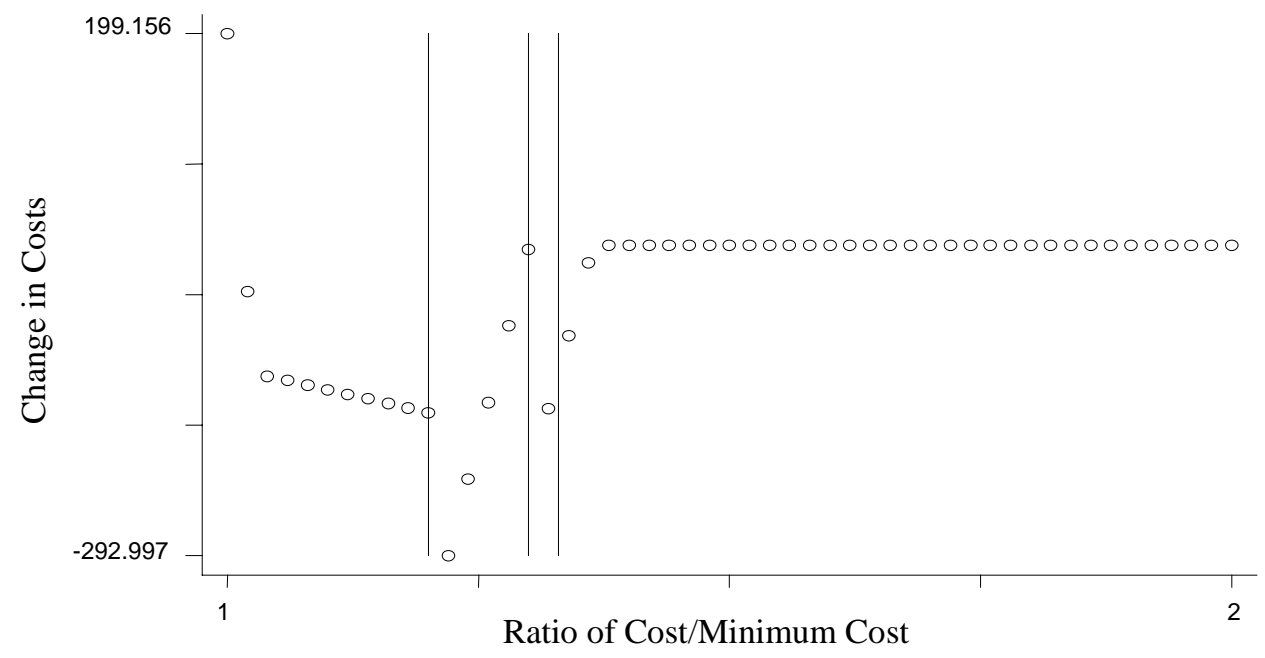

Figure 3h: Changes in Costs, 1997-1998

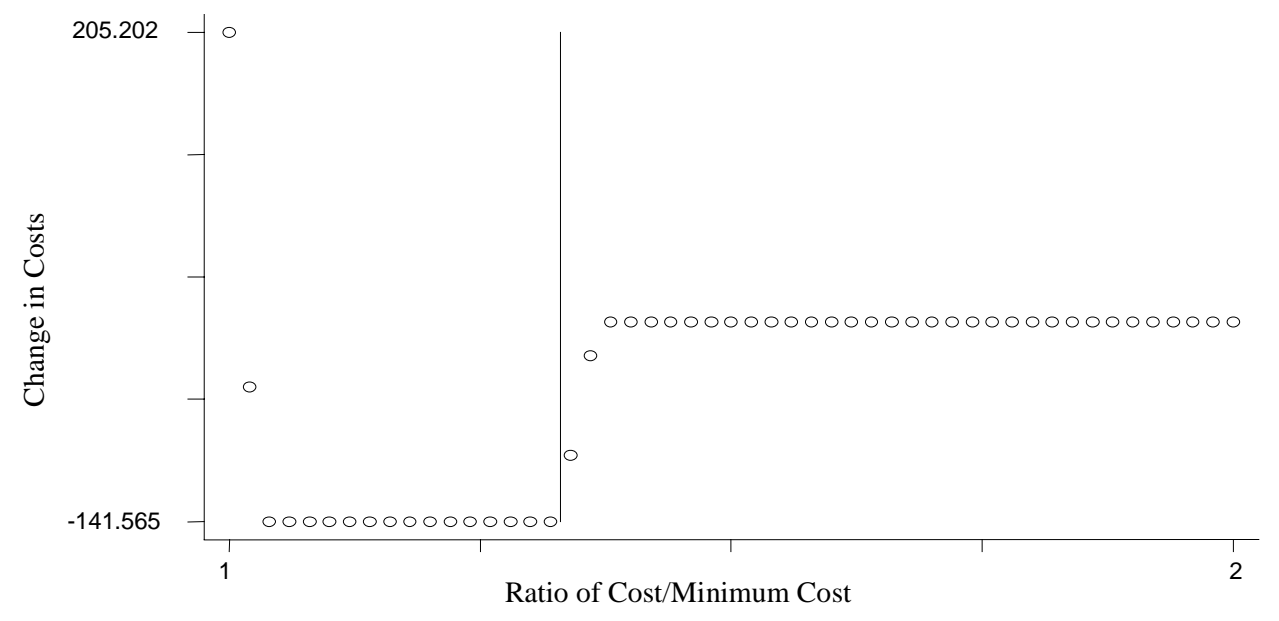


In Figures $3 \mathrm{a}$ to $3 \mathrm{~h}$, we have computed the changes in nominal costs between consecutive years induced by changes in the minimum wage and subsidies of each year. ${ }^{2}$ To simplify our descriptive analysis, we do not show changes in costs induced by other changes in the tax system (such as health, or pensions), even though we compute and use the exact changes in the rest of the analysis. More precisely, we assume for this computation that workers paid $w$ at the initial date will be paid exactly $w$ at the next date unless the old wage is between the old and the new minimum wage. If we consider the first three couples of years (Figures $3 \mathrm{a}$ to $3 \mathrm{c}$ ), we see that changes are solely due to increases in the minimum wage. Workers at the minimum have the largest change, whereas workers with a wage above the new nominal minimum wage have an unchanged cost (given the assumptions used for this descriptive analysis). Starting in 1993-1994, the subsidies interact with the changes in the minimum wage. The vertical lines reflect the schedule of the subsidies (at 1.1, 1.2, 1.3, and 1.33 times the minimum wage depending on the year). For instance, changes between 1993 and 1994 are characterized by a small increase in the SMIC, a decrease in payroll taxes for workers with wage between the SMIC and 1.1 times the SMIC, and a smaller decrease between 1.1 and 1.2 times the minimum wage. All workers with a wage in 1993 above 1.2 times the new minimum are unaffected by these changes. The largest decrease occurs between 1995 and 1996 when the employer payroll taxes decrease by 18.2 percentage points, inducing a decrease in costs of more than 700 French Francs (120 US\$) for workers close to the minimum. Finally, Figure $3 \mathrm{~h}$ displays a very particular and interesting feature induced by the interaction of a large increase in the minimum wage and subsidies based on the same minimum wage. The minimum wage strongly increased after Jacques Chirac's election as president (a tradition in France after every presidential election). Hence, workers that were above the minimum wage in 1997 , say at 1.1 times the minimum, had a wage at the minimum in 1998. Subsidies for such workers increased, say from 10 percentage points to the maximum of 18.2 percentage points. Consequently, their cost decreased. Therefore, the minimum wage increase induced a decrease in the cost of workers who had, in 1997, a wage between the new minimum wage and 1.33 times the old minimum. We will use the structure of these various changes in our econometric analysis. Notice, however, that the various discontinuities that show up on the figures are, in reality, smoothed by the changes in the rates of other taxes, such as those paying for the health-care system or for pensions.

In addition to these reductions for low-wage workers, contracts in various youth employment programs offer either minimum wage exemptions (apprenticeship, for instance) or payroll tax exemptions. These programs were the focus of Bonnal, Fougère, and Sérandon (1997) and of Magnac (1997). To fully concentrate on the effects of the changes in the labor cost for the usual types of contracts, we will not include young workers (below 25) employed under any special program in our analysis. Indeed, they only represent a very small proportion of the employed population.

2 As in the previous Figures, the computations reflect the situation as of March of the year. 


\section{Data and First Evidence}

\subsection{Data Description}

The data were extracted from the French «Enquête Emploi» (Labor Force Survey) for the years 1990 to 1998. The sixty thousand households included in the Labor Force Survey sample are interviewed in March of three consecutive years with one-third of the households replaced each year. Every member of the household is surveyed and followed provided that he or she does not move during this three-year period. We used the INSEE research files for each of the indicated years. These files include the identifiers that allow us to follow individuals from year to year. Using these identifiers we created year-to-year matched files for the years 1990-91 to 1997-98.

The survey measures usual monthly earnings, net of employee payroll taxes but including employee income taxes, and usual weekly hours. The minimum wage is defined on an hourly basis, unfortunately the usual weekly hours measure appears to be somewhat noisy. A lot of respondents say that they work more than 39 hours per week, the legal limit. If one calculates an hourly wage, an unreasonable fraction is paid below the minimum. For instance, some high-paid young engineers declare more than 50 hours a week. Therefore, we used the monthly wage together with the full-time or parttime status to compute the total labor cost. For workers employed part-time, we used the reported weekly hours to compute their full-time equivalent monthly wage. For fulltime workers, we use the reported monthly wage.

All young workers employed in publicly-funded programs that either combined classroom education with work («apprentis», «stage de qualification» or «stage d'insertion, contrat emploi - formation») or provide subsidized low-wage employment (such as «SIVP, stage d'initiation à la vie professionnelle») were excluded from the database. All of these programs provide a legal exemption from the SMIC and from certain payroll taxes. These programs are limited to workers 25 years old and under. In addition, all workers who declared a wage below $95 \%$ of the minimum wage without reporting employment on a special scheme were not kept in the analysis file (they represent less than 5\% of the original file). Most correspond to reporting or coding errors as well as workers on special contracts who did not specify the type of contract. We also eliminated workers employed as civil servants or in the public sector since they cannot become non-employed, owing to their status.

The employment status in year $t$ is equal to one for all individuals who are employed in March of the survey year, and equal to 0 otherwise. The French Labor Force Survey definition of employment is the same as the one used by the International Labor Office: a person is employed if he or she worked for pay for at least one hour during the reference week. The definition is thus consistent with the American BLS definition.

Our control variables consist of education, age, sex, seniority, type of contract, wage, and year. Education was constructed as six categories: none; completed elementary school, junior high school, or basic vocational/technical school; completed advanced vocational/technical school; completed high school (baccalauréat); completed technical 
college; completed undergraduate or graduate university. Seniority was measured as the response to a direct question in the survey (years with the present employer). The type of contract was constructed as 3 categories: short-term contracts (CDD), temporary work, long-term contracts (CDI). Summary statistics are presented in Table A.1 in the Data Appendix.

The data on minimum wage, price index and taxes were taken from «Les Retrospectives », BMS ( Bulletin Mensuel de Statistiques, INSEE) in March of each year. The data on tax subsidies were taken from «Liaisons Sociales » (DARES) and «Séries longues sur les Salaires » ( INSEE Résultats, édition 1998).

\subsection{Descriptive Analysis}

Figure 4a presents a non-parametric estimation of the probabilities of being nonemployed at date $t+l$ conditional on being employed at date $t$ as a function of the ratio of the wage cost to the minimum wage cost for two couples of years, 1990-1991 and 1995-1996. These years were selected because the GDP growth rate were similar, but the structure of transitions does not change across years.

Figure 4a: Job Losses, 1990-91 and 1995-96, w.r.t the SMIC

○ Job Loss Prob. 90-91 $\quad \triangle$ Job Loss Prob. 95-96

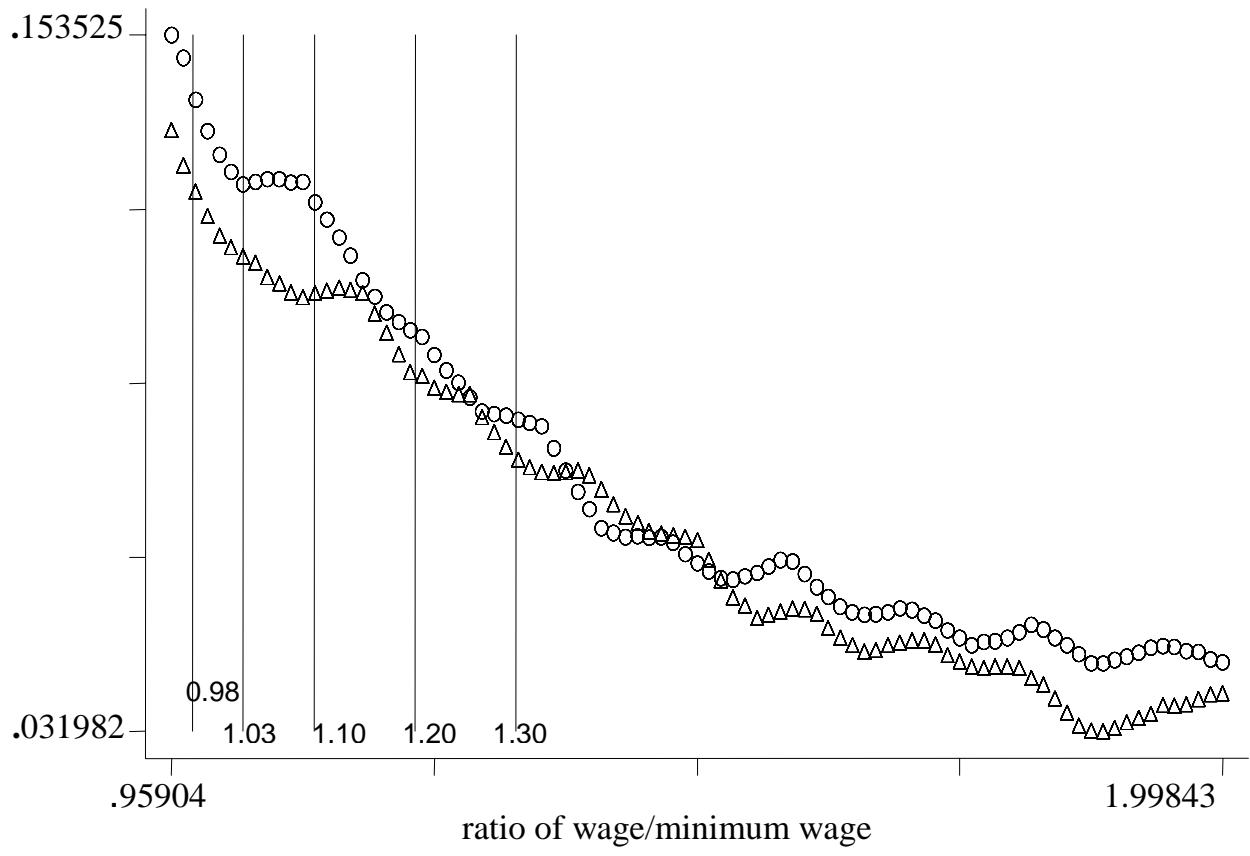


In particular, in every year workers with higher wages are less likely to become nonemployed. The vertical lines correspond, from the left to the right to $0.98,1.03,1.1,1.2$, and 1.3 times the minimum wage. Our "between" workers (our treated group) are roughly comprised between the first two lines, the "marginal" workers (our control group) are roughly comprised between the second and the third, whereas the last two lines correspond to the steps in the subsidy schedule that prevails in 1996. Considering first the 1990-1991 transitions, the "between" workers, i.e. those directly concerned by the minimum wage increase, have a higher job loss probability than the "marginal" workers, who also have a higher job loss probability than the rest of the distribution. Notice also that "marginal" workers have a roughly constant job loss probability whereas "between" workers' mirror the minimum wage cost increase shown in Figure 3a. The 1995-1996 job loss probability distribution has changed, in particular in the tax subsidy zone, where the subsidy is the largest, i.e. close to the minimum wage, where the job loss probability decreases. Indeed, the changes do not seem much stronger for the "between" than for the "marginal" workers. In fact, there is no obvious evidence of substitution between "marginal" and "between" workers in Figure 4a. Finally, notice that the difference between the two couples of years apparently disappears at 1.15 times the minimum wage.

Simultaneously, the decrease in the minimum wage cost may have favoured entry of low-wage workers. Therefore, we contrast entries over the same two couples of years. Figure $4 \mathrm{~b}$ presents non-parametric estimates of the probability of coming from nonemployment (in 1990 and 1995, respectively) for workers employed in the next year (1991 and 1996, respectively) as a function of the ratio of the wage to the minimum wage. Once again, the vertical lines correspond, from the left to the right to $0.98,1.03$, $1.1,1.2$, and 1.3 times the minimum wage. 
Figure 4b: Job Entry, 1990-91 and 1995-96, w.r.t the SMIC

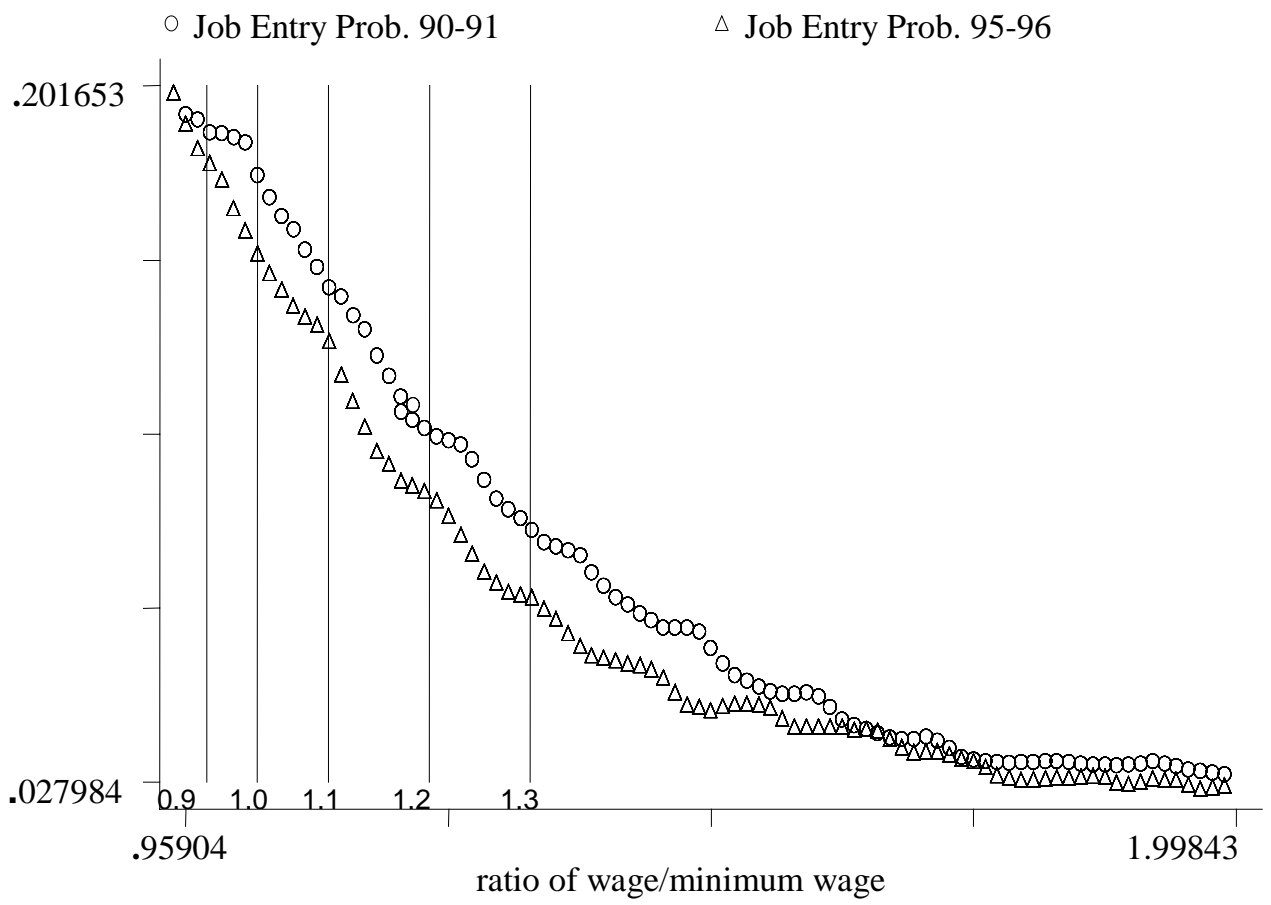

Indeed, the results do not show any obvious difference between the two couples of years, even though more entry seems to take place in the bottom of the wage distribution in all years. Indeed, business conditions were not exactly similar in those two couples of years even though they were close. This may explain the slightly larger entry in 1990-1991. Notice that "marginal workers" do not seem to benefit from the decrease in costs more than "between workers". More detailed statistical analysis is obviously needed here and will be presented in the next sections. Just note that the "marginal" workers we use as a control group in our statistical analysis, do not seem to be affected by substitution. We will come back to this question later in the analysis. We now turn to our statistical framework in order to analyze the effects of the changes in the minimum costs more systematically.

\section{The Statistical Models}

Our first interest is the analysis of the impact of minimum wage increases on transitions to non-employment of workers directly affected by the increase. Therefore, we isolate these workers in our statistical framework. From the Figures $3 \mathrm{a}$ to $3 \mathrm{~h}$ presented above, we see that years 1990 to 1992 are excellent examples of years in which the cost for 
minimum wage workers increase while that of workers just above the new minimum does not change. The large minimum wage increase that occurs between 1997 and 1998 is also an example where workers at the minimum are directly affected even though tax subsidies were already in place. In fact, workers above the new minimum up to 1.33 times the old minimum benefited from a decrease in costs. But, importantly for us, workers just above the new minimum, say between the new minimum and 1.1 times the new minimum benefit from the same decrease as workers with wage between 1.1 and 1.3 times the new minimum. Hence, in our period analysis, minimum wage costs increased by more than for all other categories of workers many times. The effects of such increases can be contrasted with the effects of decreases in costs that occurred during the same period. In particular, the above Figures show that two couples of years, 1995-1996 and 1993-1994, are undoubtedly years of decreasing cost for minimum wage workers. Furthermore, in those two couples of years, workers situated above in the wage distribution benefited less from the tax subsidies than minimum wage workers.

Therefore, our statistical analyses will contrast outcomes of workers most affected by the changes - increases in the minimum wage or decreases in the minimum wage costs after implementation of tax subsidies - with those closest to them in the wage distribution but either not affected or less affected by the changes.

A look at the same Figures might lead us to use some of the discontinuities that appear in the changing costs (the statistical methods well-suited to using such discontinuities for program evaluation are presented in Angrist and Lavy, 1999, van der Klaauw, 1996; they are based on ideas of Campbell, 1969). However, there are at least two reasons for not using this type of approach in our particular application. First, the Figures show changes that are not the only cost changes that occur in any given year. In particular, our computations of cost changes include other components of the taxes that are not shown on the graphs but are used in our statistical analysis. As already mentioned, these other components tend to smooth the changes. Furthermore, the data on wages that we use are not precise enough to locate and examine precisely the discontinuities. These wages come from a household survey, and many components of the wage cannot be isolated. For instance, a precise measure of the bonuses is essential to assess the exact situation of a worker vis-à-vis the minimum wage and, therefore, vis-à-vis tax subsidies when the wage is around 1.2 or 1.3 times the minimum. Such information is not available in the French enquête emploi. Administrative data sources would be more suited to such analysis.

\subsection{Exit}

In this section, we model the ideas discussed above. More precisely, we apply and extend Abowd, Kramarz, Lemieux, and Margolis' (1999) and Abowd, Kramarz, and Margolis' (1999) statistical framework (see also Currie and Fallick, 1996) to the study of the impact of changes in total labor costs on employment. 
Let $r m i c_{t}$ be the real minimum wage cost at date $t$ and $r c_{i, t}$ the real wage cost of worker $i$ at date $t$. Increasing costs implies $r m i c_{t+1}>r_{m i c}$ Thus, some workers have costs in year $t$ that fall between the two successive minimum wage costs:

$B_{t}=\left\{i / r m i c_{t}<r c_{i, t}<r m i c_{t+1}\right\}$ is the population caught by the increasing minimum wage cost. $\mathrm{B}_{t}$ is the treated group.

As observed in Abowd et al., the low-wage workers also have a propensity to exit employment, even after controlling for all observables, that is larger than high-wage workers. Therefore, they used as a control group workers whose wages were marginally above those directly affected by the increasing minimum wage. We follow the same route and define

$M_{t}=\left\{i / r m i c_{t+1}<=r c_{i, t}<1.1 * r m i c_{t+1}\right\}$, the population whose costs are marginally above those of the "between" group. $M$ is the control group.

Abowd et al. (id.) use a conditional logit analysis to determine whether the test group $\left(B_{t}\right)$ has a higher probability of transiting to non-employment than the control group $\left(M_{t}\right)$. Hence, following them, we estimate the model :

$$
\operatorname{Pr}\left[e_{t+1}=1 \mid e_{t}=1\right]=\mathrm{F}\left(\begin{array}{l}
x_{t} \beta+b \mathrm{I}\left(r m i c_{t} \leq r c_{t} \leq r m i c_{t+1}\right) \times\left(r m i c_{t+1}-r m i c_{t}\right) \\
+m \mathrm{I}\left(\text { rmic }_{t+1}<r c_{t} \leq\left(r m i c_{t+1} \times \mathrm{I} . \mathrm{I}\right)\right) \times\left(r m i c_{t+1}-r m i c_{t}\right)
\end{array}\right)
$$

where $\mathrm{F}$ is the standard logistic function. I(.) equals 1 if the individual satisfies the condition, and 0 otherwise, $x_{t}$ is the vector of all relevant observable individual characteristics: it includes dummy variables for years, education (6 groups), age (8 groups), part-time indicator, short-term contract indicator, potential experience and square, seniority and square, and a cubic in the wage.

This first analysis corresponds to a first difference approach. If the two groups are structurally different, then differences in the above estimates will only reflect heterogeneity between $B_{t}$ and $M_{t}$. Indeed, as a first approach, it is important to contrast years in which the cost is increasing with years in which the cost is decreasing. Existence of differences would provide direct evidence of the impact of minimum wage hikes. However, model (1) is welldefined in years of increasing minimum wage costs but it has to be modified in years of decreasing minimum wage costs. To do this, we define the "between" group as workers in the bottom of the wage distribution, i.e. $B_{t}=\left\{i / 0.98 * r m i c_{t}<r c_{i, t}<1.05 * r m i c_{t}\right\}$ and "marginal" workers as $M_{t}=\left\{i / 1.05 * r m i c_{t}<=r c_{i, t}<1.15 * r m i c_{t}\right\}$. Hence, we estimate the above equation with the appropriate modification of the two groups:

$$
\operatorname{Pr}\left[e_{t+1}=1 \mid e_{t}=1\right]=\mathrm{F}\left(\begin{array}{l}
x_{t} \beta+b \mathrm{I}\left(0.98 \times r m i c_{t} \leq r c_{t}<1.05 \times r m i c_{t}\right) \times\left|r m i c_{t+1}-r m i c_{t}\right| \\
+m \mathrm{I}\left(1.05 \times r m i c_{t+1} \leq r c_{t}<1.15 \times r m i c_{t}\right) \times\left|r m i c_{t+1}-r m i c_{t}\right|
\end{array}\right.
$$


To go further into the direction of a difference-in-difference analysis, one must use all years simultaneously and control for unobserved time-constant unobserved heterogeneity in the two groups by including indicators for $B_{t}$ and $M_{t}$. The resulting estimating equation is:

$$
\operatorname{Pr}\left[e_{t+1}=1 \mid e_{t}=1\right]=\mathrm{F}\left(\begin{array}{l}
x_{t} \beta+b_{0} \mathrm{I}\left(B_{t}\right)+m_{0} \mathrm{I}\left(M_{t}\right) \\
+b \mathrm{I}\left(B_{t}\right) \times\left(r m i c_{t+1}-r m i c_{t}\right) \\
+m \mathrm{I}\left(M_{t}\right) \times\left(r m i c_{t+1}-r m i c_{t}\right)
\end{array}\right)
$$

where we have a constant for each group, $B_{t}$ and $M_{t}$, together with an interaction with changes in the minimum wage cost. Note that the coefficients $b$ and $m$ cannot be separately identified from $b_{0}$ and $m_{0}$ in the above equation unless there is enough variation in the changes of minimum wage cost. So, we need to include years of decreasing costs in the estimation. As above, we proceed by defining "between" workers in years of decreasing costs as $B_{t}=\left\{i / 0.98^{*} r m i c_{t}<r c_{i, t}<1.05^{*}\right.$ rmic $\left._{t}\right\}$ and "marginal" workers as $M_{t}=\left\{i / 1.05 * r^{2 m i c} c_{t}<=r c_{i, t}<1.15 * r m i c_{t}\right\}$.

Finally, to account for possible asymmetries in the estimates between years of increasing and years of decreasing costs, we re-estimate the previous equation allowing for different parameters for $b$ and $m$ in years of increasing minimum wage cost and in years of decreasing minimum wage cost. The final equation is:

$$
\operatorname{Pr}\left[e_{t+1}=1 \mid e_{t}=1\right]=\mathrm{F}\left(\begin{array}{l}
x_{t} \beta+b_{0} \mathrm{I}\left(B_{t}\right)+m_{0} \mathrm{I}\left(M_{t}\right) \\
+b_{i} \mathrm{I}\left(B_{t}\right) \times\left(r m i c_{t+1}-r m i c_{t}\right) \times \mathrm{I}\left(r m i c_{t+1}-r m i c_{t}>0\right) \\
+m_{i} \mathrm{I}\left(M_{t}\right) \times\left(r m i c_{t+1}-r m i c_{t}\right) \times \mathrm{I}\left(r m i c_{t+1}-r m i c_{t}>0\right) \\
+b_{d} \mathrm{I}\left(B_{t}\right) \times\left(r m i c_{t}-r m i c_{t+1}\right) \times \mathrm{I}\left(r m i c_{t}-r m i c_{t+1}>0\right) \\
+m_{d} \mathrm{I}\left(M_{t}\right) \times\left(r m i c_{t}-r m i c_{t+1}\right) \times \mathrm{I}\left(r m i c_{t}-r m i c_{t+1}>0\right)
\end{array}\right.
$$

where the index $i$ stands for a year of increasing minimum wage cost and index $d$ stands for a year of decreasing minimum wage cost.

\subsection{Entry}

Decreasing wage cost implies $r m i c_{t}>r m i c_{t+1}$ : thus, some workers have costs in year $t+1$ that are $\underline{\text { between }}$ the two successive minimum wage costs, $B_{t}=\left\{i / r m i c_{t+1}<r c_{i, t+1}<\right.$ $\left.r m i c_{t}\right\}$. Hence, it constitutes the population liberated by the decreasing minimum wage cost. Indeed, if workers are paid their marginal product, this decrease in costs should allow non-employed workers to enter jobs. And, as above, we define $M_{t}=\left\{i / \mathrm{rmic}_{t}<\right.$ $\left.r c_{i, t+1}<r m i c_{t} * 1.1\right\}$, the population with costs marginally above those of the "between" group. 
As Abowd et al. (id.), we use a conditional logit analysis to determine whether the "between" group $(B)$ has a higher probability of coming from non-employment than the "control" group $(M)$.

Hence, we estimate the following model :

$$
\operatorname{Pr}\left[e_{t}=1 \mid e_{t+1}=1\right]=\mathrm{F}\left(\begin{array}{l}
x_{t+1} \beta+b \mathrm{I}\left(\text { rmic }_{t+1} \leq r c_{t+1} \leq r m i c_{t}\right) \times\left(\text { rmic }_{t}-r m i c_{t+1}\right) \\
+m \mathrm{I}\left(\text { rmic }_{t}<r c_{t+1} \leq\left(r m i c_{t} \times 1.1\right)\right) \times\left(\text { rmic }_{t}-r m i c_{t+1}\right)
\end{array}\right)
$$

where all variables being defined as above.

Notice that the statistical framework is different in its interpretation from the previous one since it adopts a retrospective perspective instead of a prospective one. In the classic evaluation problem, some workers receive a treatment and the statistician examines future outcomes. Here, we face the reverse situation since, in equation (5), we condition on output, i.e. the future location in the wage distribution to examine the past situation. In fact, this is an example of the classic case-control studies in which the statistician examines what past environment may have caused a future outcome, say what are the specific living conditions of persons affected by a particular disease. Prentice and Pyke (1979) show that the logistic framework that we use in our approach is adequate and that the interpretation of the resulting coefficients in a retrospective study is similar to those obtained in a prospective study.

We will also estimate models equivalent to (2) and to the difference-in-difference equations (3) and (4), as explained for increasing costs, with the appropriate modifications:

$$
\operatorname{Pr}\left[e_{t}=1 \mid e_{t+1}=1\right]=\mathrm{F}\left(\begin{array}{l}
x_{t} \beta+b_{0} \mathrm{I}\left(B_{t}\right)+m_{0} \mathrm{I}\left(M_{t}\right) \\
+b \mathrm{I}\left(B_{t}\right) \times\left(r m i c_{t}-r m i c_{t+1}\right) \\
+m \mathrm{I}\left(M_{t}\right) \times\left(r m i c_{t}-r m i c_{t+1}\right)
\end{array}\right)
$$

and

$$
\operatorname{Pr}\left[e_{t}=1 \mid e_{t+1}=1\right]=\mathrm{F}\left(\begin{array}{l}
x_{t} \beta+b_{0} \mathrm{I}\left(B_{t}\right)+m_{0} \mathrm{I}\left(M_{t}\right) \\
+b_{i} \mathrm{I}\left(B_{t}\right) \times\left(r m i c_{t+1}-r m i c_{t}\right) \times \mathrm{I}\left(r m i c_{t+1}-r m i c_{t}>0\right) \\
+m_{i} \mathrm{I}\left(M_{t}\right) \times\left(r m i c_{t+1}-r m i c_{t}\right) \times \mathrm{I}\left(r m i c_{t+1}-r m i c_{t}>0\right) \\
+b_{d} \mathrm{I}\left(B_{t}\right) \times\left(r m i c_{t}-r m i c_{t+1}\right) \times \mathrm{I}\left(r m i c_{t}-r m i c_{t+1}>0\right) \\
+m_{d} \mathrm{I}\left(M_{t}\right) \times\left(r m i c_{t}-r m i c_{t+1}\right) \times \mathrm{I}\left(r m i c_{t}-r m i c_{t+1}>0\right)
\end{array}\right)
$$




\section{Results}

\subsection{Exit}

Table 1 presents the estimation results of models (1) - employment to non-employment transitions in years of increasing minimum wage cost, 1990 to 1992 - and (2) employment to non-employment transitions in the first year of strongly decreasing minimum wage cost, 1995. As expected, Table 1 shows that a strong and significant difference between two consecutive groups is observed between the treated group, workers caught up by the increase in the minimum wage, and the control group, those workers with wage just above the new minimum wage cost in years of increasing minimum wage costs. The resulting differential elasticity, i.e. between the treated and the control group, is roughly equal to -1.5 .

Hence, a one percent increase in the minimum wage cost induces a 1.5 percent increase in the probability that a minimum wage worker becomes non-employed. The resulting estimates of equation (2) for year 1995, the first year in which the subsidy for a minimum wage worker was equal to 18.2 points, are markedly different. The difference between treated workers and the control group has the opposite sign and is not significantly different from zero. ${ }^{3}$ It is important to remember that a decrease in costs affects only employers and not the benefits (health insurance, pensions,...) that accrue to the workers, hence the workers' labor supply is unaffected by these changes.

3 We do not report estimates for men and women separately since they are quite close to those given in Table 1. Furthermore, estimates by age groups show that workers around 30 are those most affected by the increases in the minimum wage. 


\begin{tabular}{|l|llll|}
\hline \multicolumn{7}{|c|}{ Table 1: Estimated Effects of Real Minimum Wage Cost Increases and Decreases On } \\
Subsequent Employment Probability: 1990-1992 and 1995
\end{tabular}

Notes: Number of observations: 60,470 for years 1990 to 1992; 21,695 for year 1995 . Exclude workers on special youth employment contracts, civil servants, workers employed in public firms, and workers with a wage below $0.95 *$ SMIC. Estimation of logistic model (1) for years 1990 to 1992, model (2) for year 1995 by maximum-likelihood. Other variables are the wage (with its square and cube), education (6 categories), seniority (and square), age (8 categories), indicator for short-term contracts, indicator for temporary work, indicator for male, and year dummies.

We conclude from this first analysis that there are strong differences between years of increasing and years of decreasing minimum wage costs. Workers caught up by the increase of the minimum wage tend to lose their job more often than "marginal" workers. However, there are ways to go from these two simple difference analyses to a difference-in-difference analysis by estimating model (3) in which the effects are assumed to be symmetric. The estimates are presented in Table 2 . 


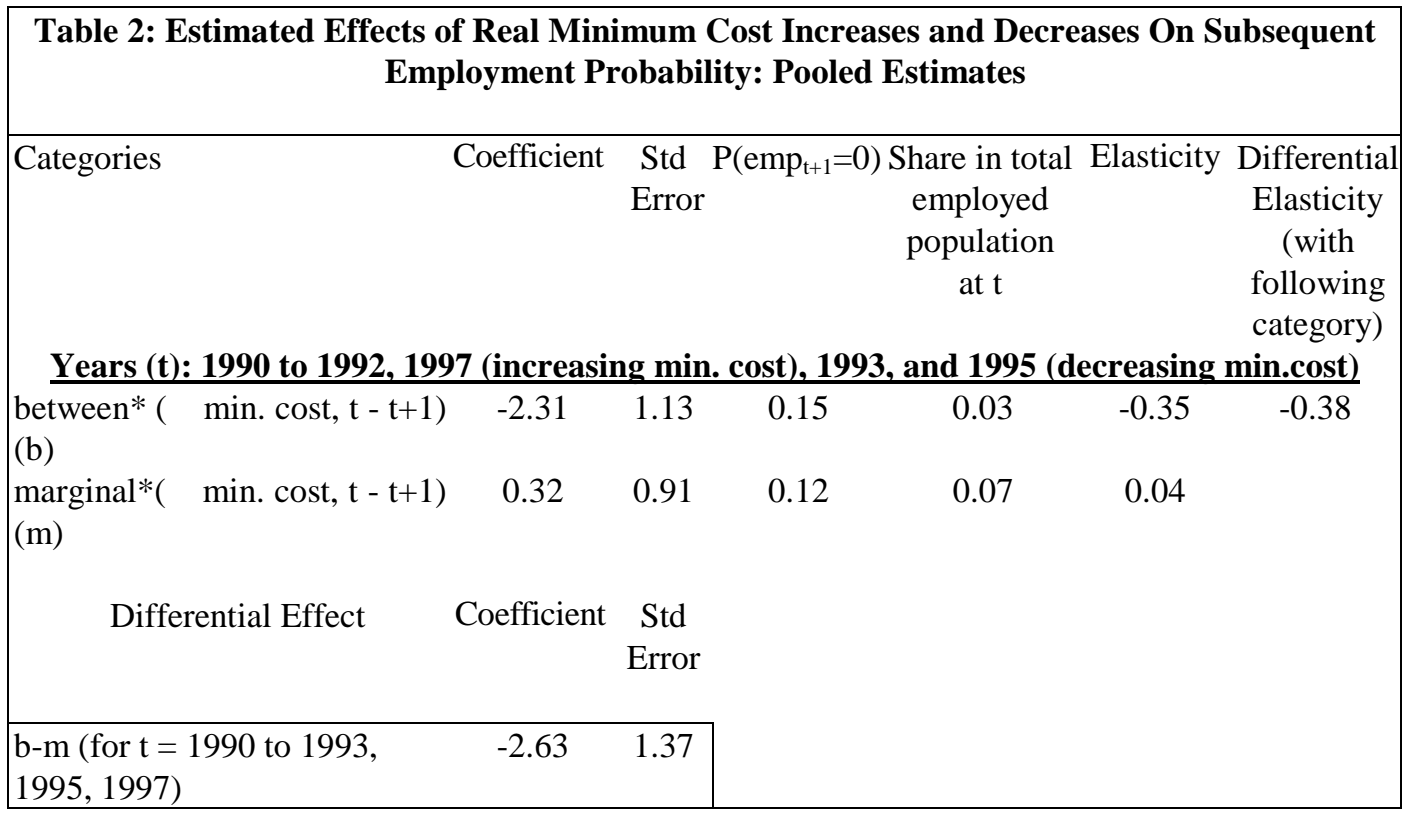

Notes: Number of observations: 124,689 for years 1990 to 1993, 1995, and 1997. Estimation of model (3). Includes an indicator for the between group and an indicator for the marginal group. All other notes as in Table 1.

The difference-in-difference estimates of the effect of a $1 \%$ increase of the minimum wage cost, -0.38 , are smaller than those presented in Table 1 , but are still significantly different from zero. Remember that this model assumes that the effects of increases, years 1990 to 1992, and 1997 and of decreases, years 1993, and 1995, in the minimum wage cost are symmetric.

Table 3 presents the estimates of model (4) in which the symmetry is not assumed. 
Table 3: Estimated Effects of Real Minimum Wage Cost Increases and Decreases On Subsequent Employment Probability: Pooled Estimates, Asymmetric Effects

\begin{tabular}{|c|c|c|c|c|c|c|}
\hline Categories & Coefficient & $\begin{array}{l}\text { Std } \\
\text { Error }\end{array}$ & $\mathrm{P}\left(\mathrm{emp}_{\mathrm{t}+1}=0\right)$ & $\begin{array}{l}\text { Share in } \\
\text { total } \\
\text { employed } \\
\text { population } \\
\text { at } \mathrm{t}\end{array}$ & Elasticit & $\begin{array}{c}\text { Differential } \\
\text { Elasticity } \\
\text { (with } \\
\text { following } \\
\text { category) }\end{array}$ \\
\hline Years $(t): 1990$ to 1992,1997 & increasing 1 & nin. $\mathrm{cc}$ & ost), 1993, ar & d $1995(\mathrm{dec}$ & reasing & in.cost) \\
\hline Between* | min. cost, $\mathrm{t}-\mathrm{t}+1 \mid$ & -14.39 & 3.53 & 0.16 & 0.02 & -2.30 & -1.56 \\
\hline $\begin{array}{l}\left(\text { for } t \text { with increasing min.cost): } b_{i}\right. \\
\text { Marginal } * \text { min. cost, } t-t+1 \mid \\
\text { (for } t \text { with increasing min.cost): } \mathrm{m}_{\mathrm{i}}\end{array}$ & -6.19 & 3.36 & 0.12 & 0.04 & -0.74 & \\
\hline Between*| min. cost, $t-t+1 \mid$ & -2.68 & 1.71 & 0.14 & 0.01 & -0.38 & -0.03 \\
\hline $\begin{array}{l}\text { (for } \mathrm{t} \text { with decreasing min.cost): } b_{d} \\
\text { Marginal } * \text { min. cost, } t-t+1 \mid \\
\text { (for } t \text { with decreasing min.cost): } m_{d}\end{array}$ & -2.85 & 1.53 & 0.12 & 0.03 & -0.34 & \\
\hline Differential Effect & Coefficient & Std & & & & \\
\hline & & Error & & & & \\
\hline $\begin{array}{l}b_{i}-m_{i} \\
\text { (for } t=1990 \text { to } 1992,1997)\end{array}$ & -8.20 & 2.75 & & & & \\
\hline $\begin{array}{l}b_{d}-m_{d} \\
(\text { for } t=1993,1995)\end{array}$ & 0.17 & 1.53 & & & & \\
\hline $\begin{array}{l}b_{i}-m_{i}-\left(b_{d}-m_{d}\right) \\
\text { (for } t=1990 \text { to } 1993,1995,1997)\end{array}$ & -8.37 & 3.14 & & & & \\
\hline
\end{tabular}

Notes: As in Table 2.

Allowing for distinct coefficients in years of increasing costs and in years of decreasing costs exacerbates the previous results. The estimated elasticity is as large as in Table 1, 1.5 , but now it is based on a difference-in-difference analysis. Remember that, in both model (3) and model (4), we have an indicator function for the "between" group and for the "marginal" group. Hence, the resulting estimates control for the impact of minimum wage cost changes on top of the heterogeneity that is specific to each group.

The conclusion of the above analysis is clear: transitions to non-employment in year $t+1$ of workers employed in year $t$ and paid between the old and the new minimum wage costs in a year of increasing minimum wage costs are strongly and adversely affected; a $1 \%$ increase in the minimum wage cost induces a $1.5 \%$ increase in the probability of job loss. Notice however that the overall impact on the whole labor market is small since this group represents 3 to $4 \%$ of the workforce. 


\subsection{Entry}

Up to now, we have examined transitions from employment to non-employment. In this subsection, we turn to the symmetric analysis: the impact of tax subsidies on the entry of workers. In particular, we want to see if workers who were previously unemployable - not productive enough given the prevailing minimum wage cost - become employed after the decrease in the minimum wage cost.

As a starting point, and similarly to the analysis of increasing costs, we estimate model (4) in years of decreasing costs as well as in years of increasing costs. These first results are presented in Table 4 .

Table 4: Estimated Effects of Real Minimum Wage Cost Decreases and Increases On Prior Employment Probability: 1991-1993, 1994, 1996, and 1998

\begin{tabular}{|c|c|c|c|c|c|c|}
\hline Categories & Coefficient & $\begin{array}{l}\text { Std } \\
\text { Error }\end{array}$ & $\mathrm{P}\left(\mathrm{emp}_{\mathrm{t}}=0\right)$ & $\begin{array}{l}\text { Share in } \\
\text { total } \\
\text { employed } \\
\text { population } \\
\text { at } t+1\end{array}$ & Elasticity & $\begin{array}{l}\text { Differential } \\
\text { Elasticity } \\
\text { (with } \\
\text { following } \\
\text { category) }\end{array}$ \\
\hline \multicolumn{7}{|c|}{ Years $(t+1): 1991$ to 1993 (increasing minimum cost): } \\
\hline between*| min. cost, $\mathrm{t}-\mathrm{t}+1 \mid(\mathrm{b})$ & -7.44 & 2.61 & 0.19 & 0.04 & -1.41 & \multirow[t]{2}{*}{-0.92} \\
\hline$\underset{(\mathrm{m})}{\operatorname{marginal}}{ }^{*} \mid \min$. cost, $\mathrm{t}-\mathrm{t}+1 \mid$ & -3.26 & 2.26 & 0.15 & 0.08 & -0.49 & \\
\hline \multicolumn{7}{|c|}{ Year $(t+1): 1994$ (decreasing minimum cost): } \\
\hline between*| min. cost, $\mathrm{t}-\mathrm{t}+1 \mid(\mathrm{b})$ & -10.86 & 5.33 & 0.20 & 0.02 & -2.17 & \multirow[t]{2}{*}{-0.94} \\
\hline $\begin{array}{l}\text { marginal* } \\
(\mathrm{m})\end{array}$ & -7.70 & 3.70 & 0.16 & 0.07 & -1.23 & \\
\hline \multicolumn{7}{|c|}{ Year $(t+1): 1996$ (decreasing minimum cost): } \\
\hline between*| min. cost, $t \overline{-t+1 \mid(b)}$ & -2.72 & 1.31 & 0.20 & 0.06 & -0.54 & \multirow[t]{2}{*}{-0.43} \\
\hline $\begin{array}{l}\operatorname{marginal} * \mid \\
(\mathrm{m})\end{array}$ & -0.91 & 1.52 & 0.13 & 0.05 & -0.12 & \\
\hline \multicolumn{7}{|c|}{ Years $(t+1): 1998$ (increasing minimum cost): } \\
\hline between* ${ }^{\prime}$ min. cost, $\mathrm{t}-\mathrm{t}+1 \mid(\mathrm{b})$ & 2.90 & 5.56 & 0.10 & 0.09 & 0.29 & \multirow[t]{2}{*}{0.36} \\
\hline $\begin{array}{l}\text { marginal } \\
(\mathrm{m})\end{array}$ & -0.85 & 5.50 & 0.08 & 0.09 & -0.07 & \\
\hline Differential Effect & Coefficient & $\begin{array}{c}\text { Std } \\
\text { Error }\end{array}$ & & & & \\
\hline $\mathrm{b}-\mathrm{m}$ (for $\mathrm{t}+1$ from 1991 to 1993 ) & -4.18 & 2.99 & & & & \\
\hline $\mathrm{b}-\mathrm{m}($ for $\mathrm{t}+1=1994)$ & -3.16 & 5.78 & & & & \\
\hline$b-m($ for $\mathrm{t}+1=1996)$ & -1.81 & 1.73 & & & & \\
\hline$b-m($ for $t+1=1998)$ & 3.76 & 6.43 & & & & \\
\hline
\end{tabular}

Notes: Number of observations: 60,428 for years $(t+1) 1991$ to 1993 ; 21,465 for 1994; 21,707 for 1996; 16,379 for 1998. All other notes as in Table 1 . 
Apparently, in years of decreasing minimum wage costs such as 1994 and 1996, workers that are employed in year $t+1$ at a cost between the new and the old minimum wage come significantly more often from non-employment than workers employed at a cost just above the old minimum. However, for the years 1991 to 1993 that are years of increasing minimum wage cost, the same result seems to hold. One may conclude that workers who are at the bottom of the wage distribution enter more often from nonemployment than workers located elsewhere in the wage distribution. Results obtained for years of decreasing costs would be due to pure unobserved heterogeneity. However, it is interesting to consider year 1998. Between 1997 and 1998, the minimum wage increased quite strongly after Jacques Chirac's election as French president. As explained previously, this increase mechanically decreased the cost of workers paid above the new minimum because of the tax subsidies. Therefore, the cost of "between" workers vis-à-vis "marginal" workers increased even more than the minimum wage increase. And, this large cost change seems to have had an impact on the entry of workers from non-employment. This is the only year in which workers in the bottom of the wage distribution do not come from non-employment more often than those just above in the same distribution. To examine this issue further, we estimated model (6) and model (7), that are appropriate to examine entry in a difference-in-difference framework. The estimates of these models are presented in Tables 5 and 6 . We restricted the pooled analyses to the later years of the period in order to look for some evidence of the benefit of tax subsidies on entry; unreported estimates including all years showing no such benefits.

Table 5: Estimated Effects of Real Minimum Wage Cost Decreases and Increases On Prior Employment Probability: Pooled Estimates

\begin{tabular}{|c|c|c|c|c|c|c|}
\hline Categories & Coefficient & \multicolumn{2}{|c|}{$\begin{array}{l}\text { Std } \mathrm{P}\left(\mathrm{emp}_{\mathrm{t}}=0\right) \\
\text { Error }\end{array}$} & $\begin{array}{l}\text { Share in } \\
\text { total } \\
\text { employed } \\
\text { population } \\
\text { at } \mathrm{t}+1 \\
\end{array}$ & \multicolumn{2}{|c|}{$\begin{array}{l}\text { Elasticity Differential } \\
\text { Elasticity } \\
\text { (with } \\
\text { following } \\
\text { category) } \\
\end{array}$} \\
\hline \multicolumn{7}{|c|}{ Years (t+1): 1997, 1998 (increasing min. cost), 1994, and 1996 (decreasing min.cost) } \\
\hline between* $(\Delta$ min. cost, $\mathrm{t}-\mathrm{t}+1)(\mathrm{b})$ & -1.08 & 1.16 & 0.16 & 0.05 & -0.17 & -0.27 \\
\hline marginal $*(\Delta$ min. cost, $\mathrm{t}-\mathrm{t}+1)(\mathrm{m})$ & 0.75 & 1.31 & 0.13 & 0.06 & 0.10 & \\
\hline Differential Effect & Coefficient & $\begin{array}{c}\text { Std } \\
\text { Error }\end{array}$ & & & & \\
\hline $\mathrm{b}-\mathrm{m}($ for $\mathrm{t}+1=1994,1996$ to 1998$)$ & -1.83 & 1.52 & & & & \\
\hline
\end{tabular}

Notes: Number of observations: 80,772. All other notes as in Table 2.

In Table 5, effects are assumed to be symmetric between cost increases and cost decreases. In Table 6, we assume as in Table 3 that the effects are not necessarily symmetric. 


\begin{tabular}{|lccccc|}
\hline \multicolumn{5}{|c|}{ Table 6: Estimated Effects of Real Minimum Wage Cost Decreases and Increases On Prior } \\
Employment Probability: Pooled Estimates, Asymmetric Effects
\end{tabular}

Notes: As in Table 5.

Both Tables show similar results. There is evidence of a small and insignificant effect: low-wage workers seem to come more often from non-employment in years of cost decrease than in years of cost increase. Notice also that in Table 6 , the only coefficient that is significantly different from zero is that of "between" workers in years of costs decreases. But, most other standard errors are too large to yield a significant differential effect. And, as mentioned earlier, this admittedly small effect seems to exist only in the final years of the panel. In particular, it comes from the couple of years 1997-1998. In a context of tax subsidies, the large minimum wage increase that took place after Chirac's election appear to have deterred firms from hiring low-wage workers from the pool of non-employed. Even if it is not significant, this effect did not exist at the beginning of our sample period, in particular between 1991 and 1993 when the minimum wage also 30 
increased. Therefore, the tax subsidies may have changed the behavior of French employers. Note that such subsidies were the first ever to be implemented for low-wage workers in France, without any age restriction. Indeed, many programs for young workers include such subsidies but the tax subsidies that we examine in this article applied to all age categories.

\subsection{Are "Marginal" Workers a Good Control Group ?}

A simple competitive model of labor demand with multiple skills tells us that an increase in the cost of minimum wage workers induces separations of the low-skill workers, the "between" workers in our statistical analysis. As for workers with slightly higher-skills, our "marginal" workers, two effects are present: a scale effect that decreases demand, and a substitution effect that increases demand. The resulting outcome for this latter category is therefore ambiguous. Similarly, the impact of a decrease in the minimum wage cost has a positive effect on those workers that benefit most from the subsidies, our "between" workers, whereas the impact on "marginal" workers is once more ambiguous.

If, indeed, "marginal" workers are substituted for "between" workers when the minimum wage cost increases, our estimates of the simple difference (model (1)) are biased upwards. Can we find any evidence of such substitution ? First, notice that descriptive statistics (Table A.1 in Appendix A) show that "between" workers and "marginal" workers are very similar in most, if not all, dimensions. Now, when we examine the job loss probabilities in a year of decreasing costs, we see that "between" workers lose their jobs as frequently as "marginal" workers (Table 1 and Table 3). But, in Table 3, "marginal" workers tend to lose their jobs more often when costs increase than when costs decrease. Hence, "marginal" workers are also negatively affected by the increasing minimum wage, potentially by the diffusion of the increase higher in the wage distribution. Notice also that all our pooled estimates (Table 2 and Table 3 ) include as controls an indicator for each group, "marginal" workers as well as "between" workers. The resulting estimates in which years of increasing and decreasing costs are both included should therefore eliminate most of the potential substitution effects.

Furthermore, comparing years before implementation of the tax subsidies and after implementation, computations presented in Appendix B tend to show that most of the action does not consist of substitution between our "marginal" and our "between" workers but mostly of substitution between workers benefiting from the subsidies, i.e. with a wage just below 1.33 times the minimum (between 1.2 and 1.33, approximately), and workers with wage just above. However, evidence of such effects should be investigated more carefully based on a structural approach.

From this evidence, we may conclude that "marginal" workers are a reasonably good control group. 


\section{Conclusion}

Using longitudinal data over the $80 \mathrm{~s}$, and comparing years of increasing minimum wage costs with years of decreasing minimum costs, we show the negative effect of minimum wage cost increases on the employment of minimum wage workers. Our estimates, based on a difference-in-difference, approach suggest that the elasticity of labor demand is equal to -1.5 for this group. A similar analysis of the re-employment impact of tax subsidies gives small and insignificant positive effects on minimum wage workers. In fact, it seems that all workers in the tax subsidy zone benefit from the cost decreases. Unfortunately, identification of such effects is difficult due to the multiple phenomena that happen simultaneously. A direct analysis of the changes in employers' hiring policies in response to the implementation of the subsidies is needed but is beyond the scope of this paper. 


\section{References}

Abowd J. M., Kramarz F., Lemieux T., and D. N. Margolis (1999), "Minimum Wage and Youth Employment in France and the United States," in Youth Employment and the Labor Market, D. Blanchflower and R. Freeeman eds., University of Chicago Press, forthcoming.

Abowd J. M., Kramarz F., and D. N. Margolis (1999), "Minimum Wage and Employment in France and the United States," NBER working paper, 6996.

Angrist J., and V. Lavy (1999), "Using Maimonides' Rule to Estimate the Effect of Class Size on Scholastic Achievement," Quarterly Journal of Economics, 114, 533-575.

Bonnal L., Fougère, D., and A. Sérandon (1997), "Evaluating the Impact of French Employment Policies on Individual Labor Market Histories," Review of Economic Studies, 64, 683-713.

Brown C. (1999), "Minimum Wage, Employment, and the Distribution of Income," in Handbook of Labor Economics, O. Ashenfelter and D. Card eds., North-Holland, 3B, 2101-2163.

Brown C., Gilroy C., and A. Kohen (1982), "The Effect of the Minimum Wage on Employment and Unemployment," Journal of Economic Literature, 20, 487-528.

Campbell D.T. (1969), "Reforms as Experiments," American Psychologist, 24, 409429.

Card D., Kramarz F., and T. Lemieux, "Changes in the Relative Structure of Wages and Employment: a Comparison of the United States, Canada, and France," Canadian Journal fo Economics, 32, 843-877.

Card D., and A. Krueger (1995), Myth and Measurement: the New Economics of the Minimum Wage, Princeton University Press.

Card D., and A. Krueger (1998), "A Reanalysis of the Effect of the New Jersey Minimum Wage Increase on Employment Using Representative Payroll Data," NBER working paper 6386, American Economic Review, forthcoming.

Currie J., and B. Fallick (1996), "The Minimum Wage and the Employment of Youth," Journal of Human Resources, 31, 404-428.

DARES, various years, "Liaisons Sociales" (DARES, Ministry of Labor).

Dickens R., Machin S., and A. Manning (1998), "Estimating the Effect of Minimum Wages on Employment from the Distribution of Wages: a critical view," Labour Economics, 5, 109-134.

DiNardo J., Fortin N. M., and T. Lemieux (1996), "Labor Market Institutions and the Distribution of Wages, 1973-1992 : A Semiparametric Approach,” Econometrica, 64, 5, 1001-1044.

Dolado J., Kramarz F., Machin S., Manning A., Margolis D., and C. Teulings (1996), "The Economic Impact of Minimum Wages in Europe," Economic Policy, 23, 317-372.

Insee, various years, "Les Retrospectives", BMS ( Bulletin Mensuel de Statistiques, INSEE).

Insee, (1998) “Séries longues sur les Salaires”, INSEE Résultats. 
Lee D.S. (1999), "Wage Inequality in the United States During the 80s: Rising Dispersion or Falling Minimum Wage ?," Quarterly Journal of Economics, 114, 941-1023.

Magnac T. (1997), "State Dependence and Heterogeneity in Youth Employment Histories," Crest working paper 9747, Economic Journal, forthcoming.

Neumark D., and W. Wascher (1992), "Employment Effects of Minimum and SubminimumWages: Panel Data on State Minimum Wage Laws," Industrial and Labor Relations Review, 55-81.

Prentice R.L., and R. Pyke (1979), "Logistic Disease Incidence Models and CaseControl Studies," Biometrika, 66, 403-411.

Van der Klaauw W. (1996), "A Regression-Discontinuity Evaluation of the Effect of Financial Aid Offers on Enrollment," mimeo, New-York University. 
Appendix A: Table A.1

\begin{tabular}{|l|l|l|l|l|l|l|}
\hline & \multicolumn{2}{l|}{ Full Sample } & \multicolumn{2}{l|}{$\begin{array}{l}\text { Between } \\
\text { Workers }\end{array}$} & \multicolumn{2}{l|}{ Marginal Workers } \\
\hline Variable & Mean & $\begin{array}{l}\text { Std. } \\
\text { Dev. }\end{array}$ & Mean & Std. Dev. & Mean & Std. Dev. \\
\hline wage (french francs) & $11,607.6$ & $28,375.6$ & $5,107.9$ & $1,349.4$ & $5,593.2$ & $1,327.0$ \\
\hline tenure & 10.4 & 9.2 & 4.6 & 6.0 & 5.8 & 6.6 \\
\hline age & 40.7 & 9.4 & 36.6 & 10.4 & 37.2 & 10.2 \\
\hline sex (1=male) & 0.62 & & 0.33 & & 0.38 & \\
\hline no education & 0.19 & & 0.33 & & 0.33 & \\
\hline CAP, CEP, BEPC & 0.54 & & 0.56 & & 0.56 & \\
\hline $\begin{array}{l}\text { technical baccalauréat } \\
\text { baccalauréat (other) }\end{array}$ & 0.06 & & 0.04 & & 0.04 & \\
\hline technical university & 0.04 & & 0.03 & & 0.03 & \\
\hline university (other) & 0.08 & & 0.02 & & 0.02 & \\
\hline short-term contract & 0.08 & & 0.02 & & 0.02 & \\
\hline temporary work & 0.04 & & 0.14 & & 0.09 & \\
\hline Number of Observations & 0.01 & & 0.02 & & 0.03 & \\
\hline
\end{tabular}

Source: 1990 to 1998 waves of the French labor force survey (Enquête Emploi). 


\section{Appendix B: Transitions Within the Wage Distribution}

First, we split the wage distribution into bands, and estimate the Markov transition matrix for each pair of years. Then, starting from the same initial distribution (the average one), we can simulate the final distribution using different combinations of matrices. In particular, we want to see if the matrices corresponding to years of decreasing costs lead to a significantly different evolution of the wage (and cost) structure.

More precisely, we define 9 states:

Not Employed at date t,

Employed and $0<$ Wage $(\mathrm{t}) /$ Minwage $(\mathrm{t})<90 \%$,

Employed and $90 \%<$ Wage $(\mathrm{t}) /$ Minwage $(\mathrm{t})<110 \%$,

Employed and $110 \%<$ Wage $(\mathrm{t}) /$ Minwage $(\mathrm{t})<120 \%$,

Employed and $120 \%<$ Wage $(\mathrm{t}) /$ Minwage $(\mathrm{t})<130 \%$,

Employed and $130 \%<$ Wage (t)/Minwage $(\mathrm{t})<150 \%$,

Employed and $150 \%<$ Wage (t)/Minwage $(\mathrm{t})<200 \%$,

Employed and 200\%<Wage(t)/Minwage(t) $<350 \%$,

Employed and 350\%<Wage(t)/Minwage(t).

We define the initial distribution as the average distribution, using the cells defined above, between 1990 and 1997. For each couple of years, we multiply the initial distribution with the corresponding transition matrix. Figure B.1 shows the relative growth of each cell. Large increases occur in the zone where tax subsidies take place. Even though the GDP growth was much higher in 1994-1995 than in any other year ${ }^{4}$, we observe that the 19961997 transition is richer in low-paid jobs.

At the same time, the size of the 150-cell (that includes workers whose wages are between $130 \%$ and $150 \%$ of the minimum wage) decreased. A possible interpretation is that the cost structure is slowly adjusting, leading to substitute workers in the tax cut area for workers above the tax cut area.

Unreported statistics show that the decrease in the 150-cell is due to a lower upward mobility within the wage distribution rather than increased transitions to non-employment.

4 The French GDP growth over the period was the following: $2.2 \%$ in $1990,0.7 \%$ in 1991 , $1.3 \%$ in $1992,-1.3 \%$ in $1993,2.8 \%$ in $1994,2.1 \%$ in $1995,1.6 \%$ in 1996 , and $2.3 \%$ in 1997. 
Figure B.1

Growth of the cells

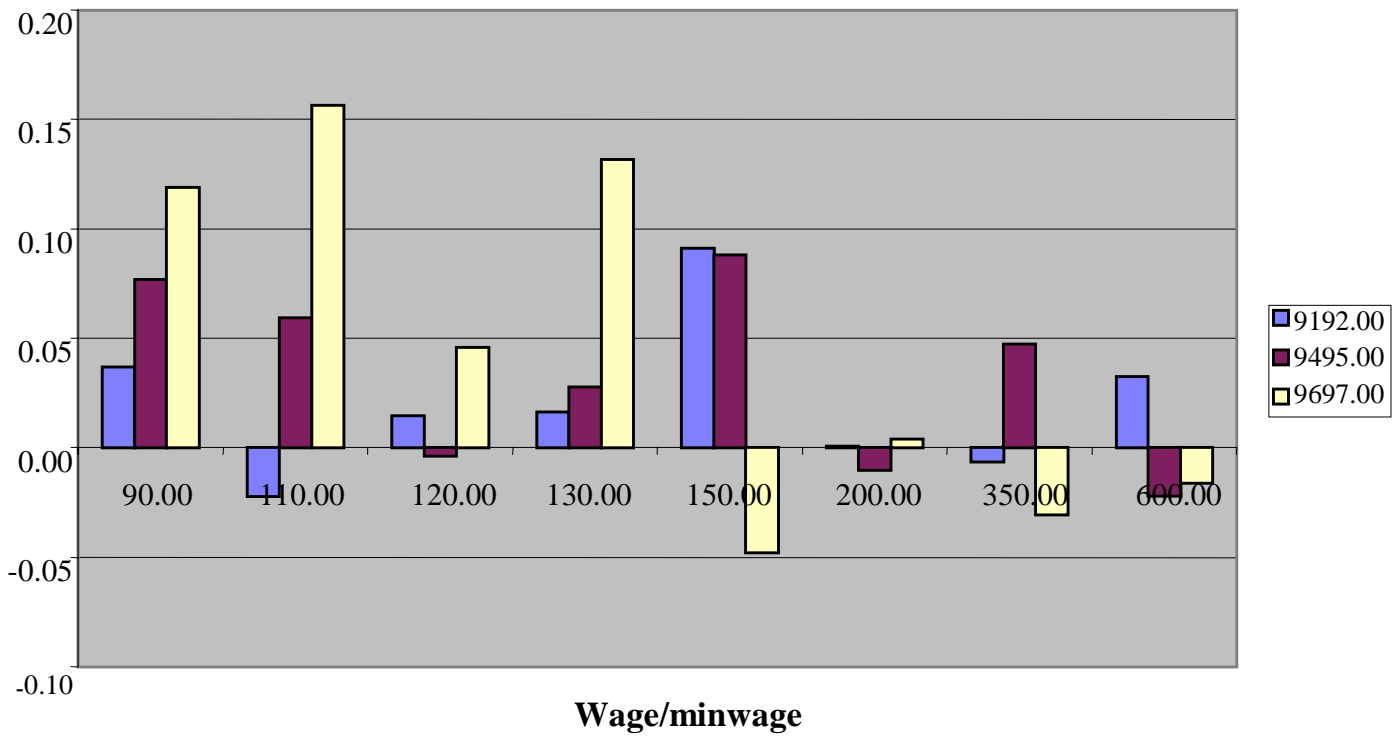

Notes: The active population is normalized to 100 . The «not employed» cell is not reported on this chart. The figure shows the relative growth of each cell based on the respective transition matrices of the indicated couple of years (9192 stands for 1991$1992, \ldots)$. The relative growth is defined as follows:100*(final size of the cell - initial size of the cell)/(initial size of the cell). The final size of the cell is the one that is obtained by applying the specified matrix: for 91-92, we use the estimated 1991-1992 transition matrix, similarly for 94-95 and 96-97. 